\title{
Uma cena DeBandável
}

\section{César Lignelli}

\author{
Universidade de Brasília \\ Brasília, DF, Brasil \\ cesarlignelli@gmail.com \\ orcid.org/0000-0003-2684-3172
}

\section{Guilherme Mayer}

Universidade de Brasília

Brasília, DF, Brasil

guigammmayer@gmail.com

orcid.org/0000-0002-1491-1812

Resumo I Objetiva-se neste artigo evidenciar tipos de relações entre humanos e não-humanos considerando o processo cênico/musical intitulado DeBanda. Para tal, brinca-se com o verbo debandar, a partir de percursos etimológicos, denotativos e do imaginário popular. Numa relação congênere à palavra, imagens atuam na configuração da rede (LATOUR, 2012) que envolve um convívio orgânicomaquinal limítrofe entre os actantes (LATOUR, 1998). Via rastros e restos demonstra-se a flexibilização da lógica marionete\marionetista nas cenas.

PALAVRAS-CHAVE:

Debandar. Rede. Actantes.

\section{On Body borders and hybrid creative} processes

\begin{abstract}
The aim of this article is to highlight types of relationships between humans and non-humans considering the scenic/musical process entitled DeBanda. To this end, we play with the verb to disband, based on etymological, denotative and popular imaginary paths. In a similar way, images act in the configuration of the network (LATOUR, 2012) which involves a borderline organic-machinery interaction between actants (LATOUR, 1998). Via tracks and remains, the flexibility of the puppet/puppeteer logic in the scenes is demonstrated.
\end{abstract}

KEYWORDS: Disband. Network. Actant.

Reflexiones sobre paisajes y fotografías de la Odisseia 116

Resumen I El objetivo de este artículo es resaltar tipos de relaciones entre humanos y no humanos considerando el proceso escénico / musical titulado DeBanda. Para ello, jugamos con el verbo disolver, partiendo de caminos imaginarios etimológicos, denotativos y populares. En una relación similar a la palabra, las imágenes actúan en la configuración de la red (LATOUR, 2012) lo que implica una interacción limítrofe orgánico-maquinaria entre los actantes (LATOUR, 1998). A través de pistas y restos, se muestra la flexibilidad de la lógica títere / titiritero en las escenas.

PALABRAS CLAVE: Desbandar. Red. Actante.

Enviado em: $16 / 08 / 2021$

Aceito em: 20/12/2021

Publicado em: $21 / 12 / 2021$ 
No sentido denotativo, debandar pode nos aproximar à ideia de fuga e de dispersão desordenada mesmo sem um motivo explícito para tal ${ }^{1}$ (ver figura 1 ).

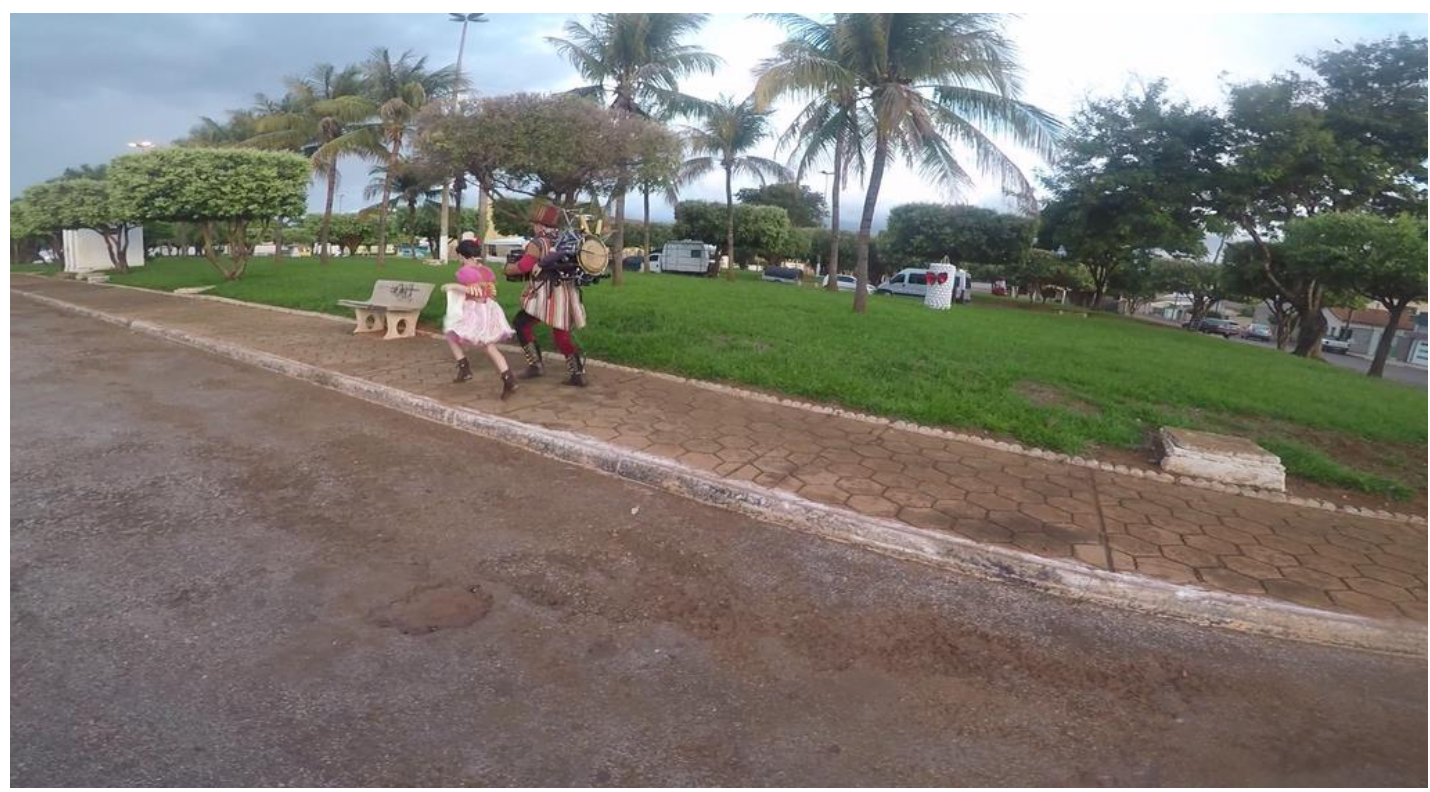

Figura 1. Foto de Sulian Vieira, Acreúna, Goiás, 2017.

Assim, um motivo crível para uma debandada, ou seja, uma ação de debandar, pode nos suscitar uma derrota. Mas não como caminho, carreira ou rumo seguido por um navio do ponto de partida ao ponto de chegada, ou seja, em seu sentido ortodrômico. A derrota referida desagua em fracasso e este tem seu sentido gregário, é sempre refletido e solidarizado multiplamente na rede que perpassa cada actante (ver figura 2).

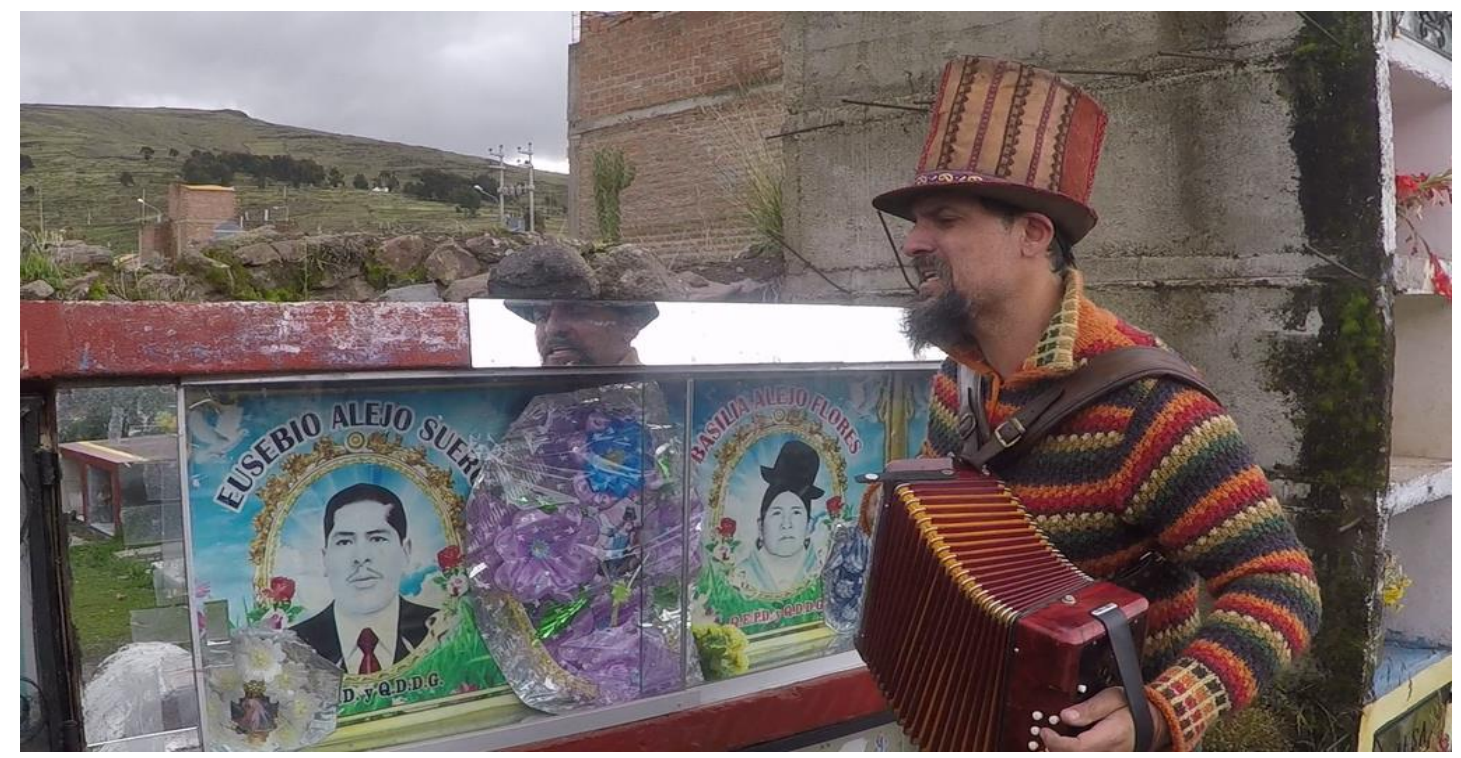

Figura 2. Foto de Sulian Vieira, Cemitério, Chucuito de Puno, Peru, 2018.

${ }^{1} \mathrm{O}$ conteúdo relativo às perspectivas denotativas e etimológicas do verbo Debandar, desenvolvido neste artigo, foram inspirados em outros materiais textuais relativos ao espetáculo. 
Essa aproximação a uma derrota conjunta também pode ser percebida etimologicamente, uma vez que "de" indica afastamento, espalhamento, e bando, do Latim bandus, grupo de pessoas que foram banidas de um lugar, ou seja, que sofreram um ato legal de expulsão por seus crimes, ainda que tal ato, por vezes, não apresenta provas explícitas para tal (ver figura 3).

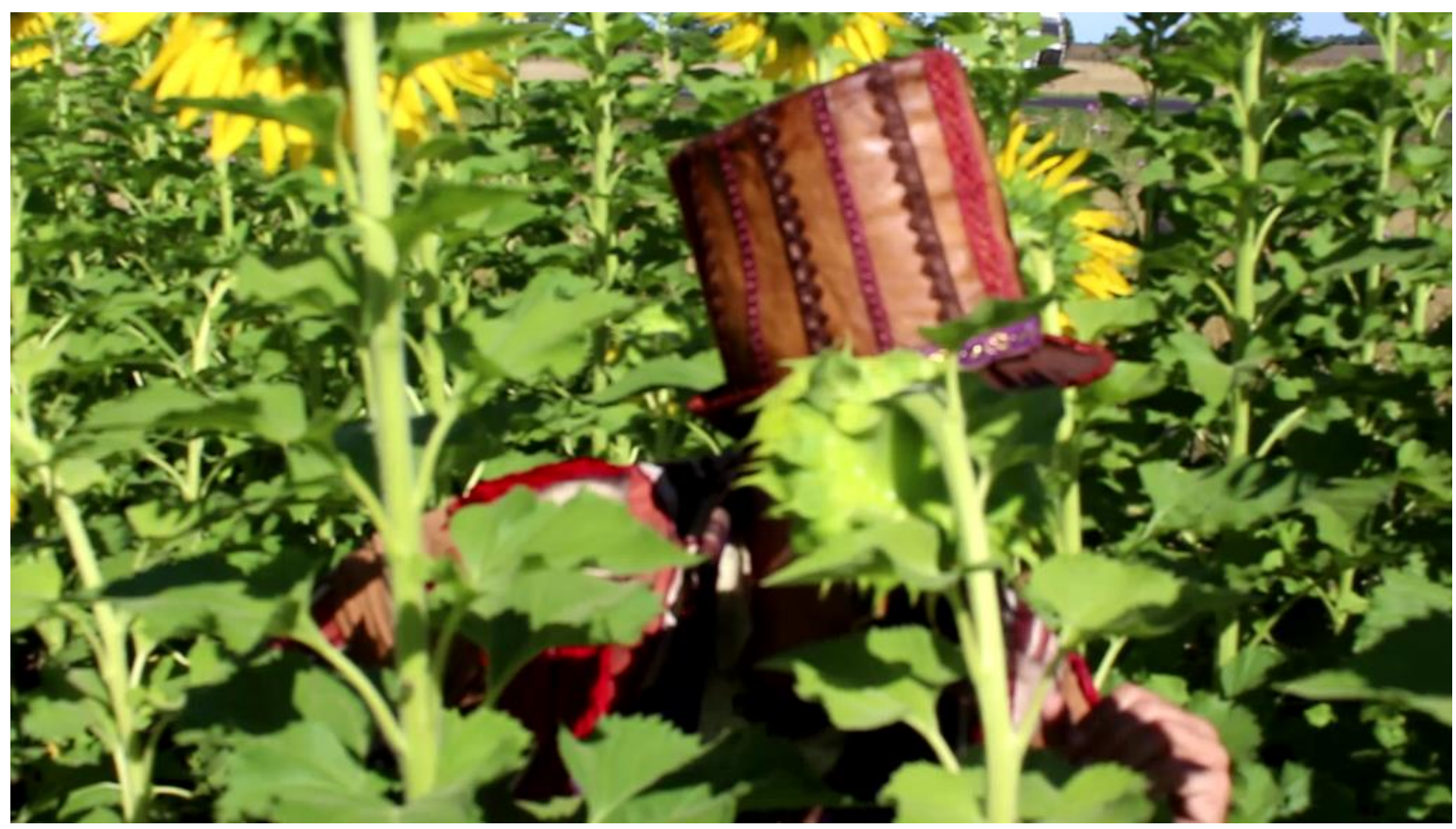

Figura 3. Foto de Sulian Vieira, Plantação de girassóis, Pehuajó, Argentina, 2018.

Curiosamente, bando e banir apresentam uma raiz etimológica semelhante, uma vez que banir advém do germânico bannan, proclamar, proibir, ordenar, e originalmente queria dizer declarar algo em público, quiçá por meios diversos para além da fala (ver figura 4).

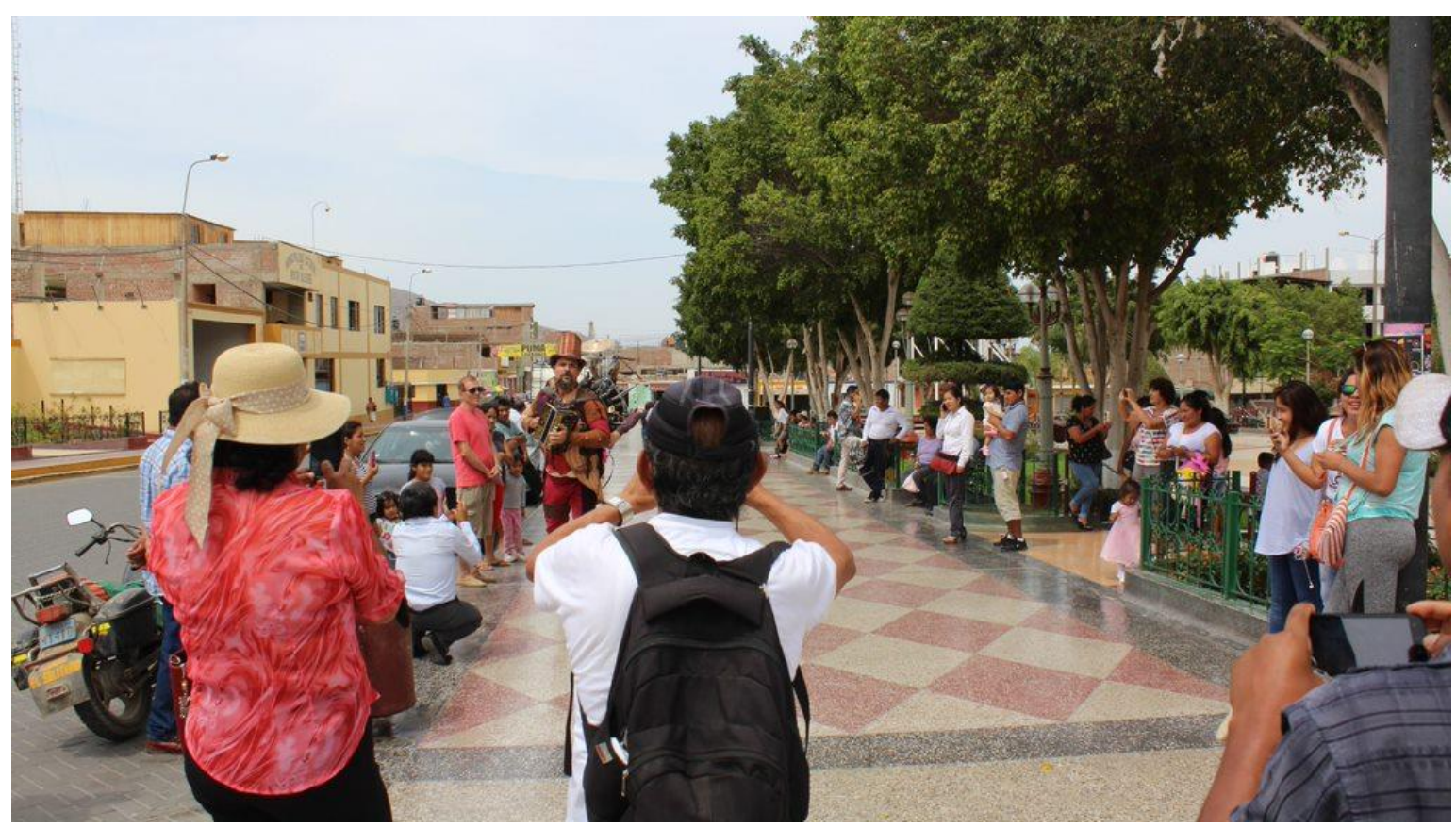

Figura 4. Foto de Sulian Vieira, Nazca, Peru, 2018. 
Ambas derivadas da base indo-europeia bha-, falar, o sentido evoluiu no germânico de falar para proibir, expelir, impedir e passou ao português através do francês banir, novamente, condenar ao exílio. Mesmo que este seja rodeado por girassóis (ver figuras 3, 4 e 5).

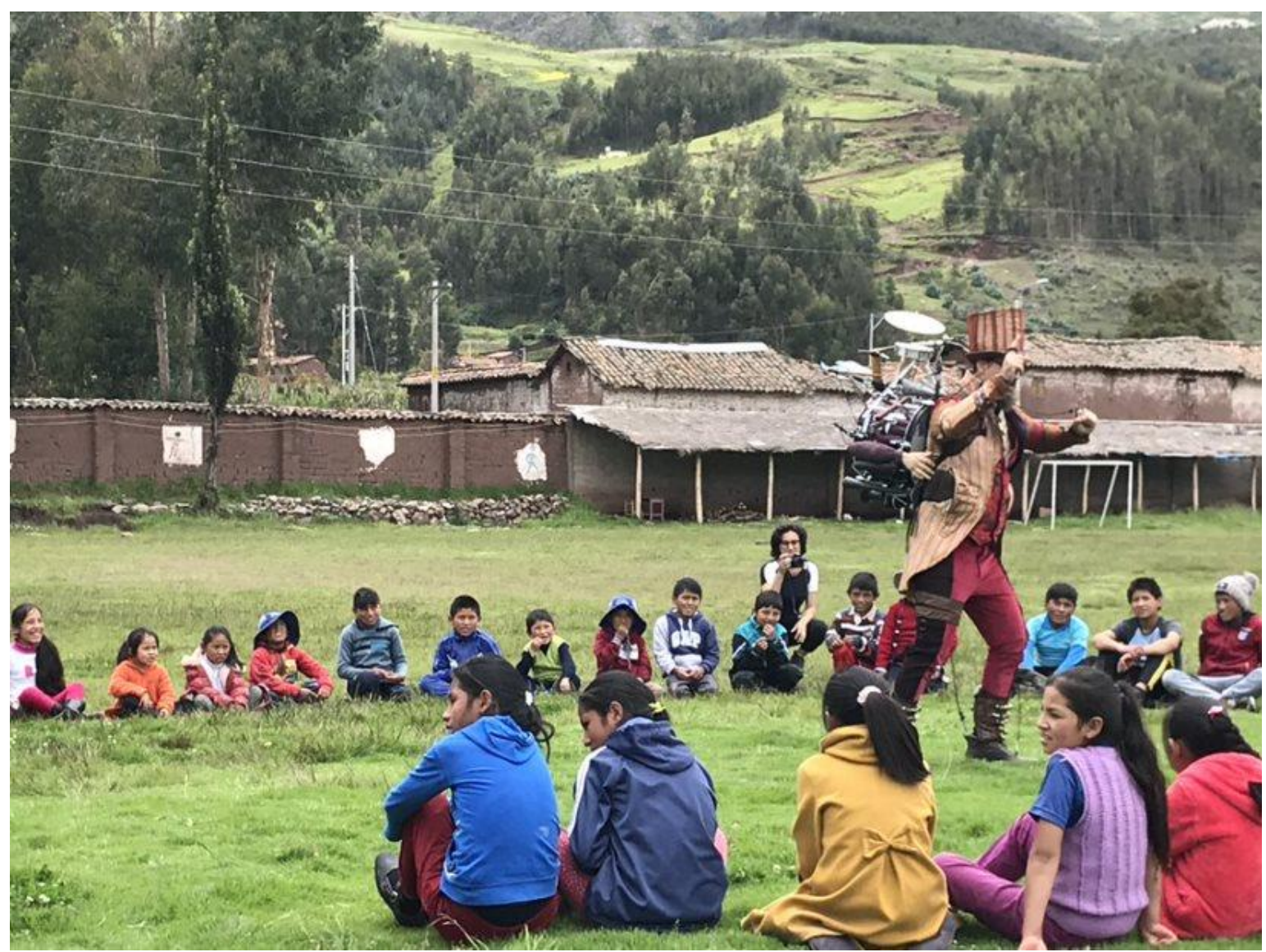

Figura 5. Foto de Ana Lignelli, Ancahuasi, Peru, 2018.

Nas acepções supracitadas temos em comum a figuração de bando como a de um coletivo banido e desventurado do qual restou apenas rastros (ver figura 6).

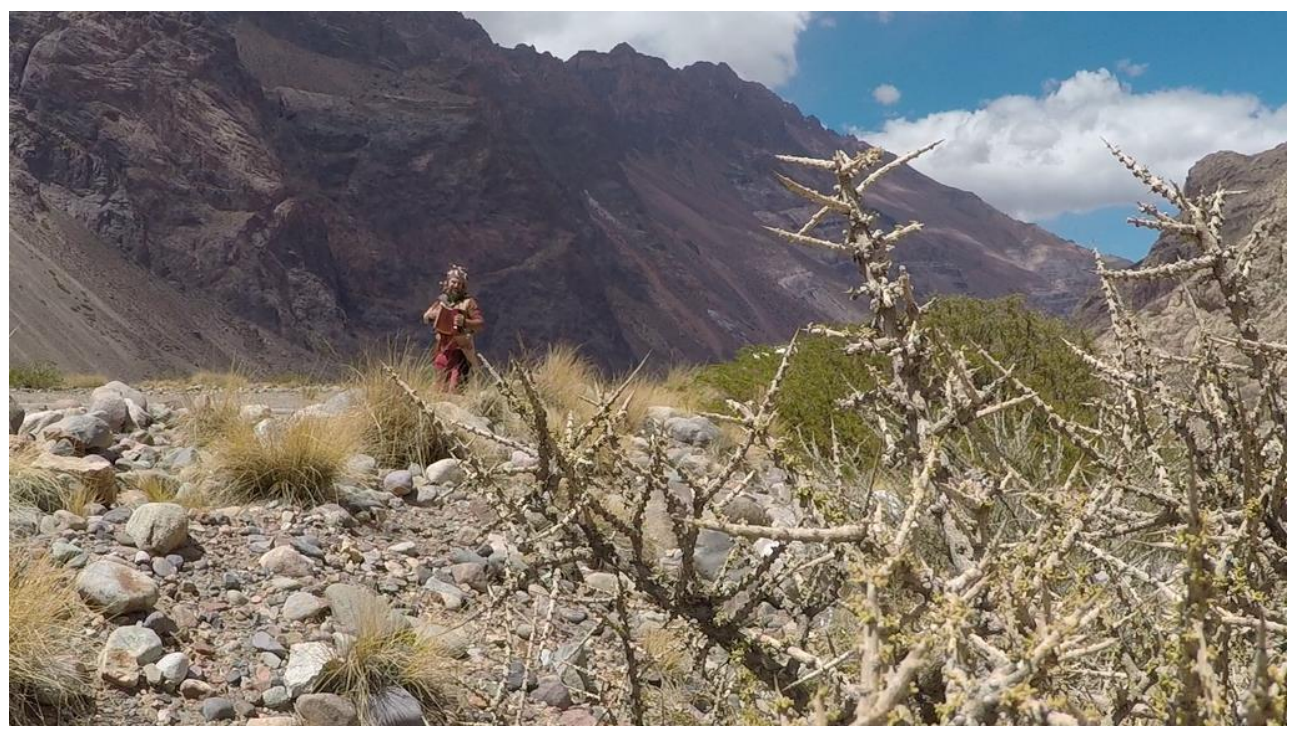

Figura 6. Foto de Sulian Vieira, Cordilheira dos Andes, Argentina, 2018. 
Já a origem germânica do feminino "banda", equivale a faixa de tecido, que se usava para distinguir as tropas entre si, e que era atravessada sobre o costado dos soldados. Numa perspectiva francesa, bande, pode ser entendida como corpo de tropa, do Gótico bandwa, marca, bandeira. Mesmo que esta seja camuflada entre a difusão lexical e a arquitetura citadina em decomposição. Mesmo que a tropa seja de mecânicos de veículos pesados (ver figuras 7 e 21).

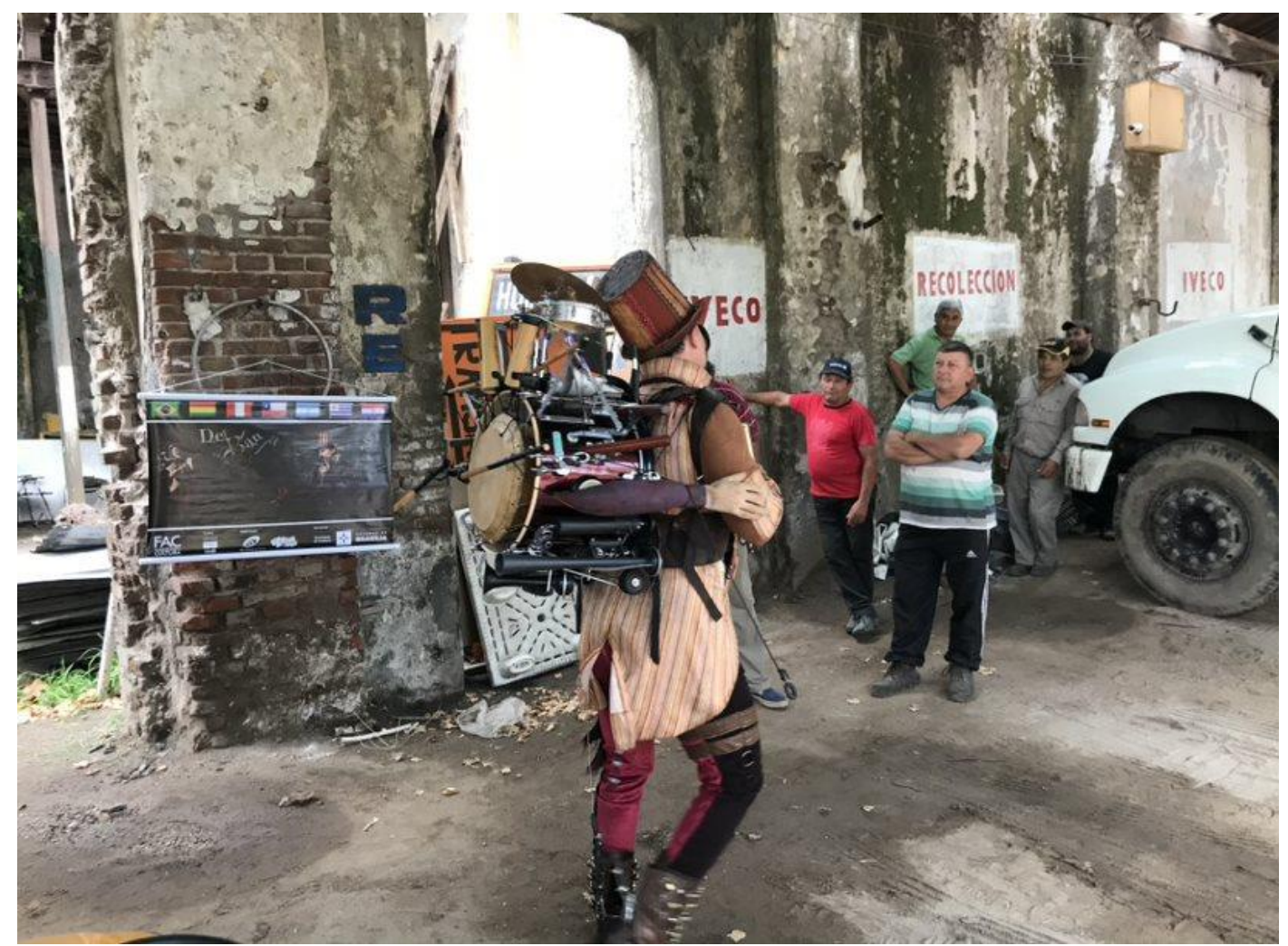

Figura 7. Foto de Sulian Vieira, Huínca Renancó, Argentina, 2018.

Percebe-se nessas três derivações que banda como faixa de tecido, tropa e bandeira evidencia um processo de distinção de coletivos no contexto belicista. Conclui-se, desta feita, que a personagem DeBanda dialoga também com estas perspectivas etimológicas, sobretudo no que diz respeito ao afastamento de delimitações quando extrapola as possibilidades sonoras dos corpos (ver figuras 2 , $5,6,7$ e 8).

Por sorte, ao elucubrar acerca dos usos coloquiais de debanda, percebemos que ela pode mencionar ao ato de andar de lado (ver figura 8), assim como de dar uma rasteira, tanto em corpos que vão ao chão (ver figura 9) quanto no sentido de passar para trás pessoas em transações de diversas ordens. 


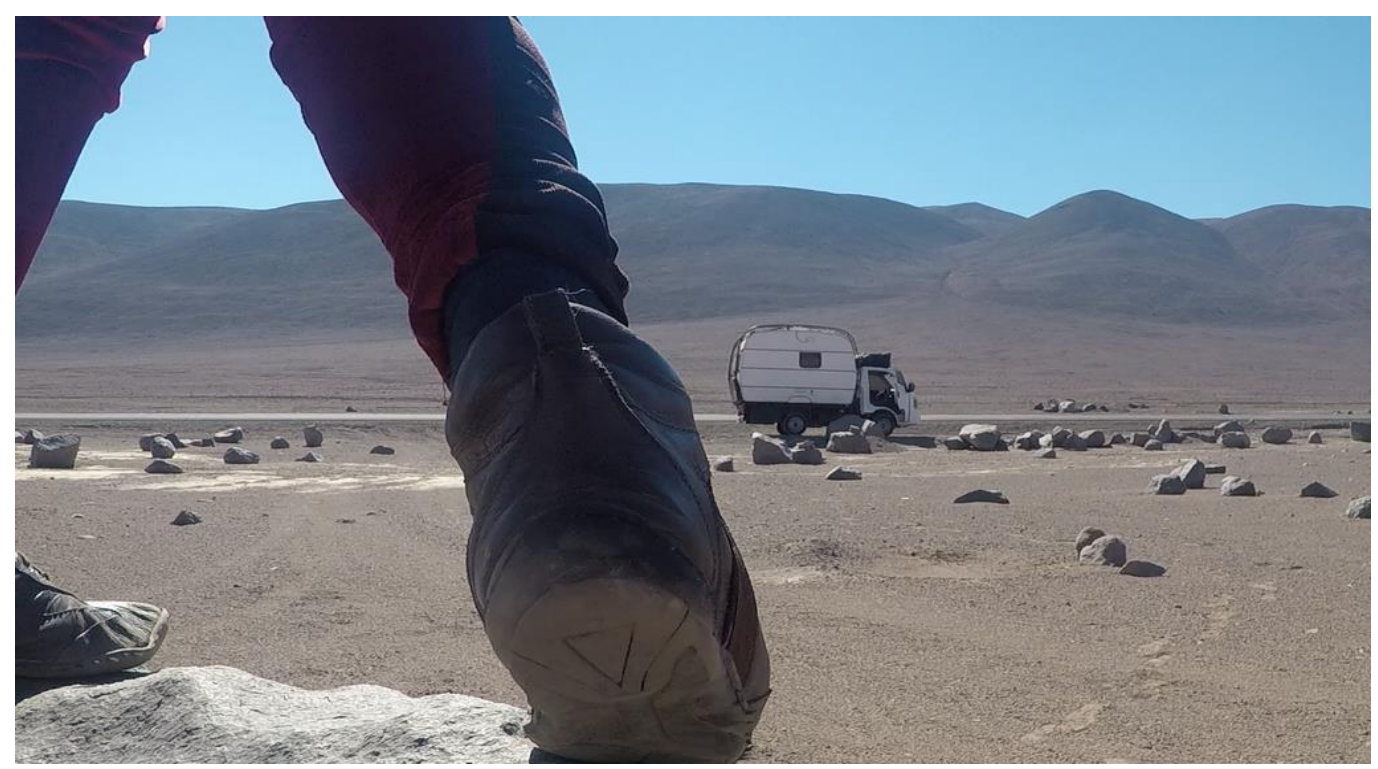

Figura 8. Foto de Sulian Vieira, Cordilheira dos Andes, Argentina, 2018.

Debandar é sinônimo de destroçar (ver figura 9).

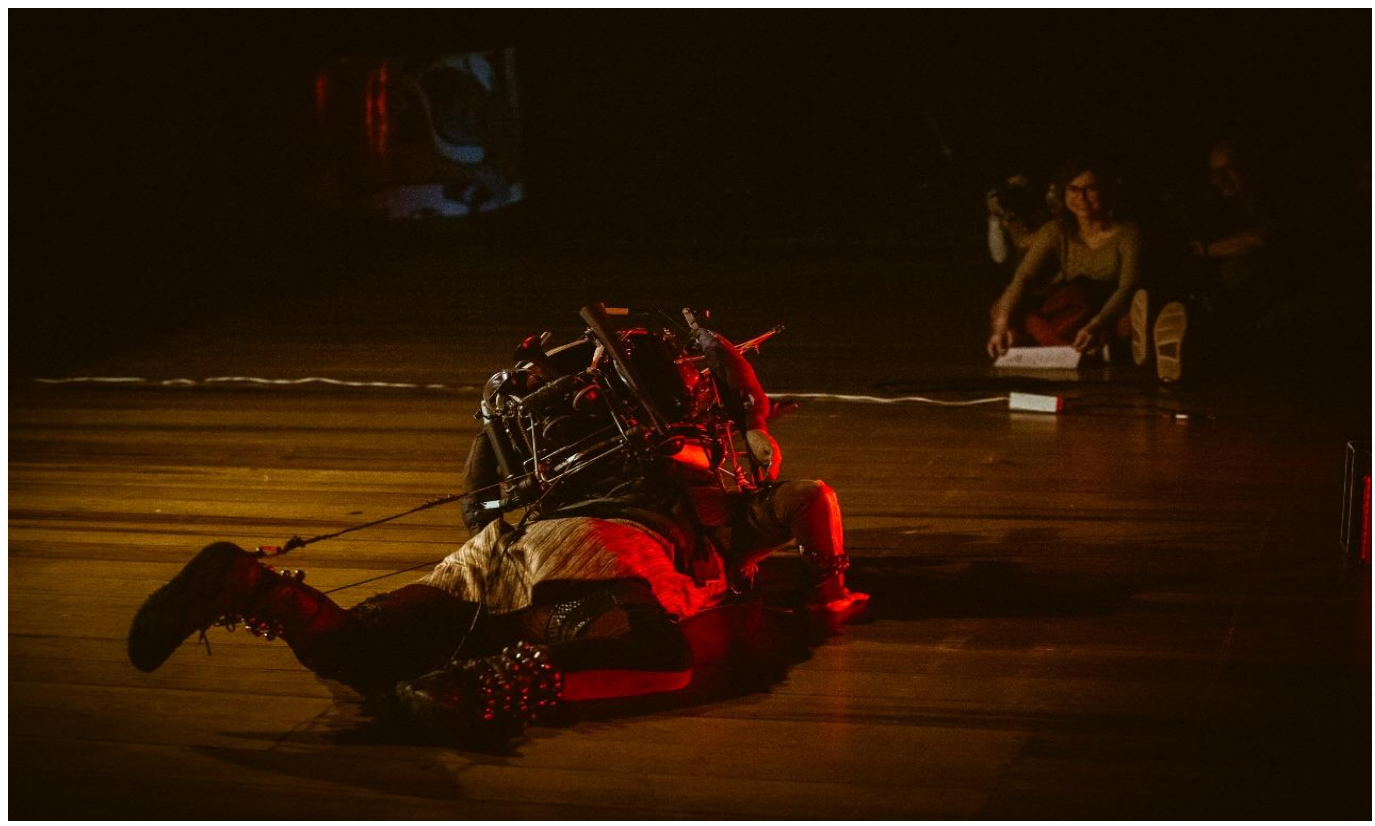

Figura 9. Foto de Diego Bressani, Festival Dulcina de Moraes, Brasília, 2019.

O mais comum dos usos talvez seja relativo a um conjunto de diversas pessoas tocando uma mesma música com instrumentos distintos (ver figuras 10,11 e 12), mesmo que este encontro se dê em uma única vez. 


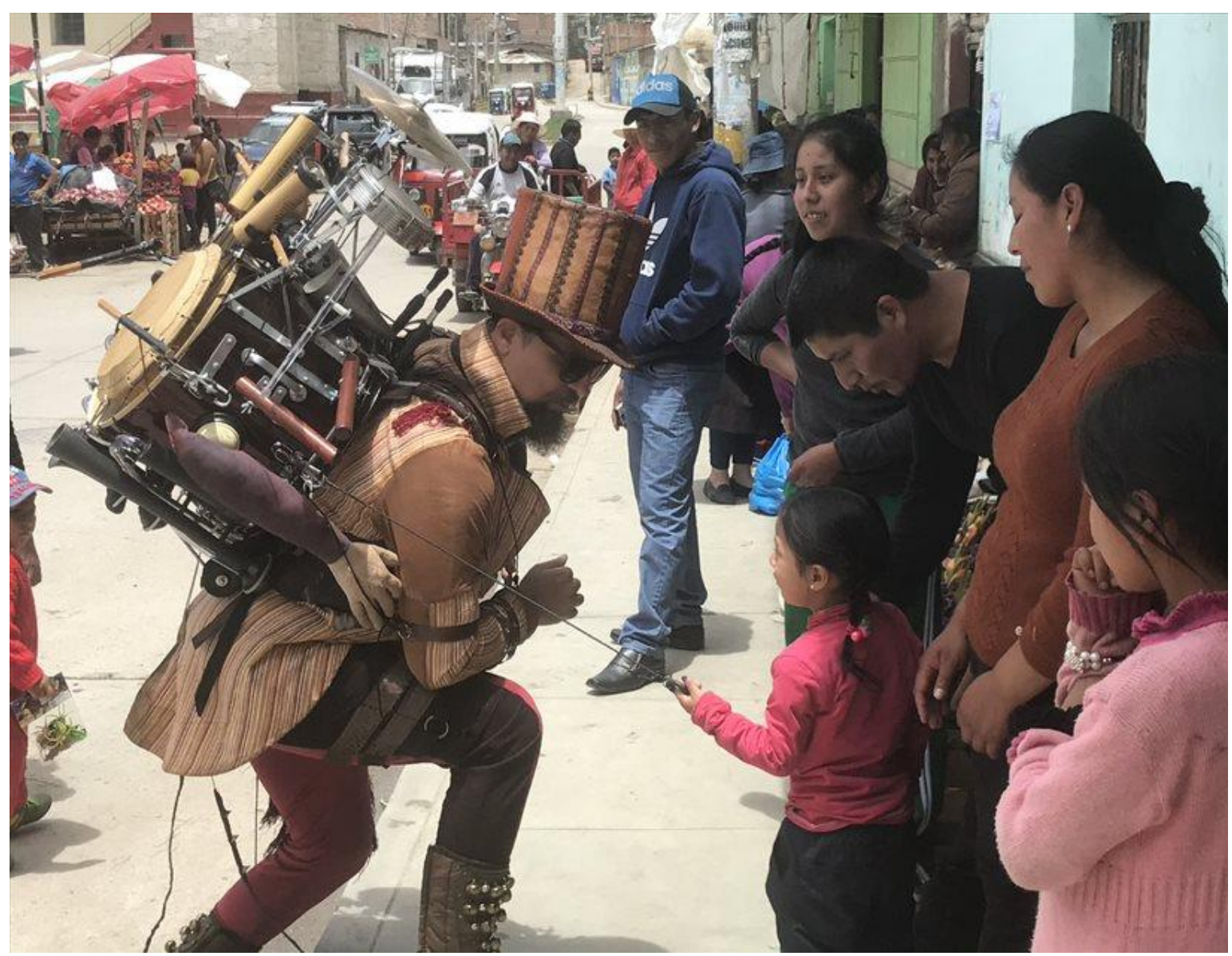

Figura 10. Foto de Ana Lignelli, Feira em Pucchio, Peru, 2018.

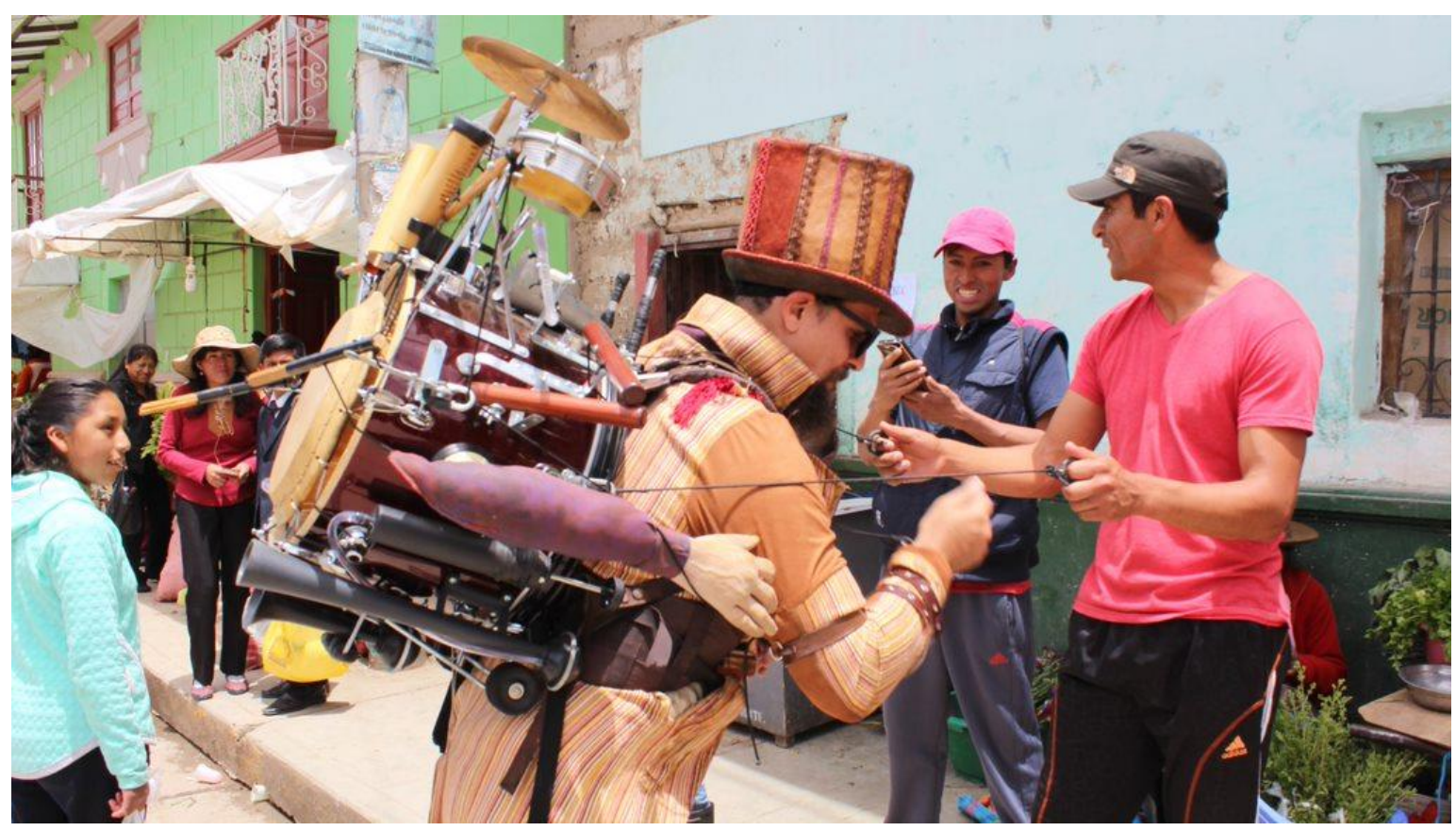

Figura 11. Foto de Ana Lignelli, Feira em Pucchio, Peru, 2018. 


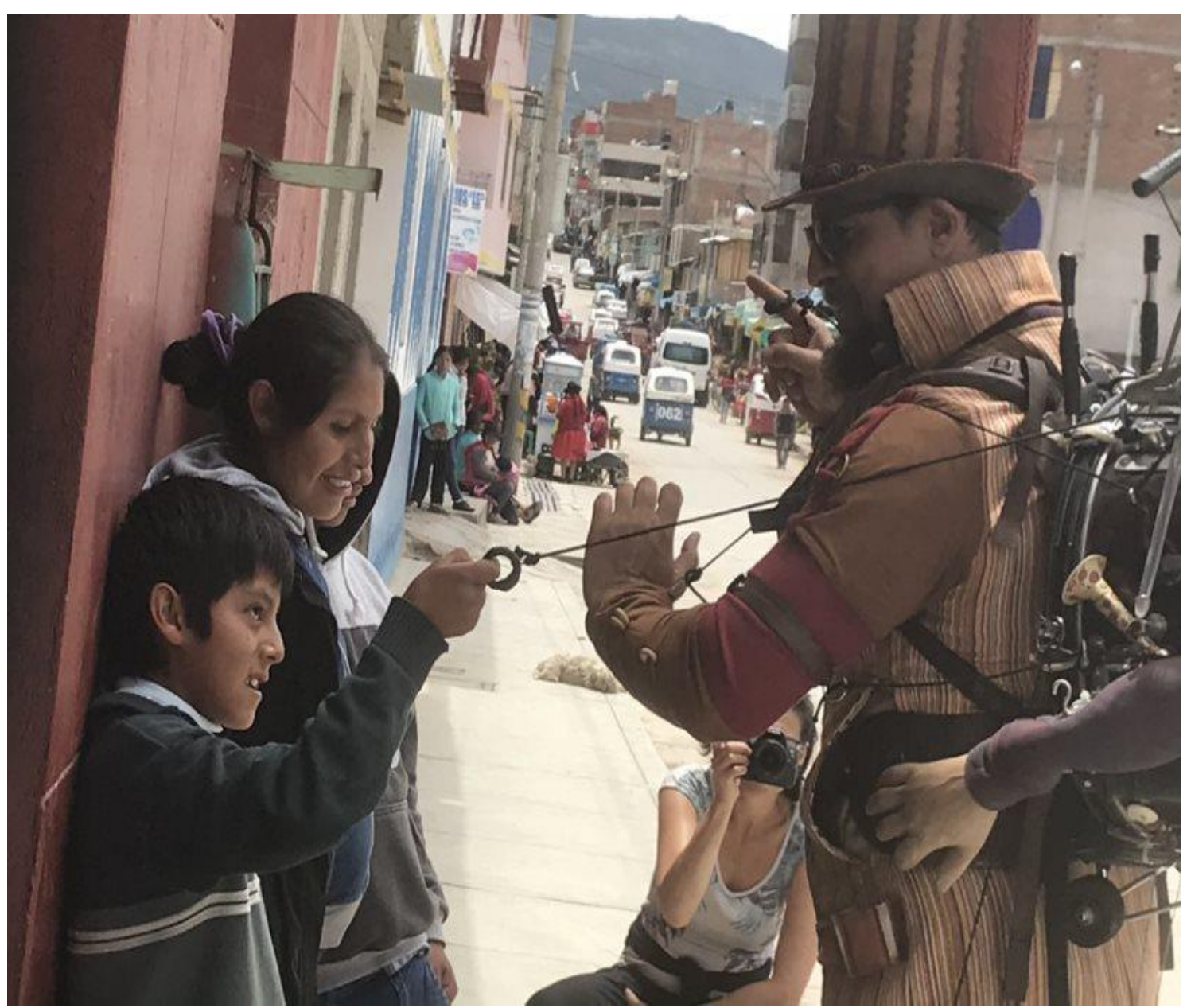

Figura 12. Foto de Ana Lignelli, Feira em Pucchio, Peru, 2018.

Divertidamente não é incomum pensarmos em uma banda como uma das partes que compõe uma bunda. Neste ponto de vista, temos a banda direita e a banda esquerda. Vulgarmente ainda é disseminado uma espécie de enigma, com ares de charada, relacionado a essa acepção: o que é maior, uma banda ou uma bunda? Para matar essa charada é preciso responder: Uma bunda. Por que? Pois tem duas bandas e um conjuntinho (ver figura 13). Mesmo que estes se camuflem em meio à multidão e ainda se disfarcem por debaixo de uma cauda de fraque vintage de matizes circenses. 


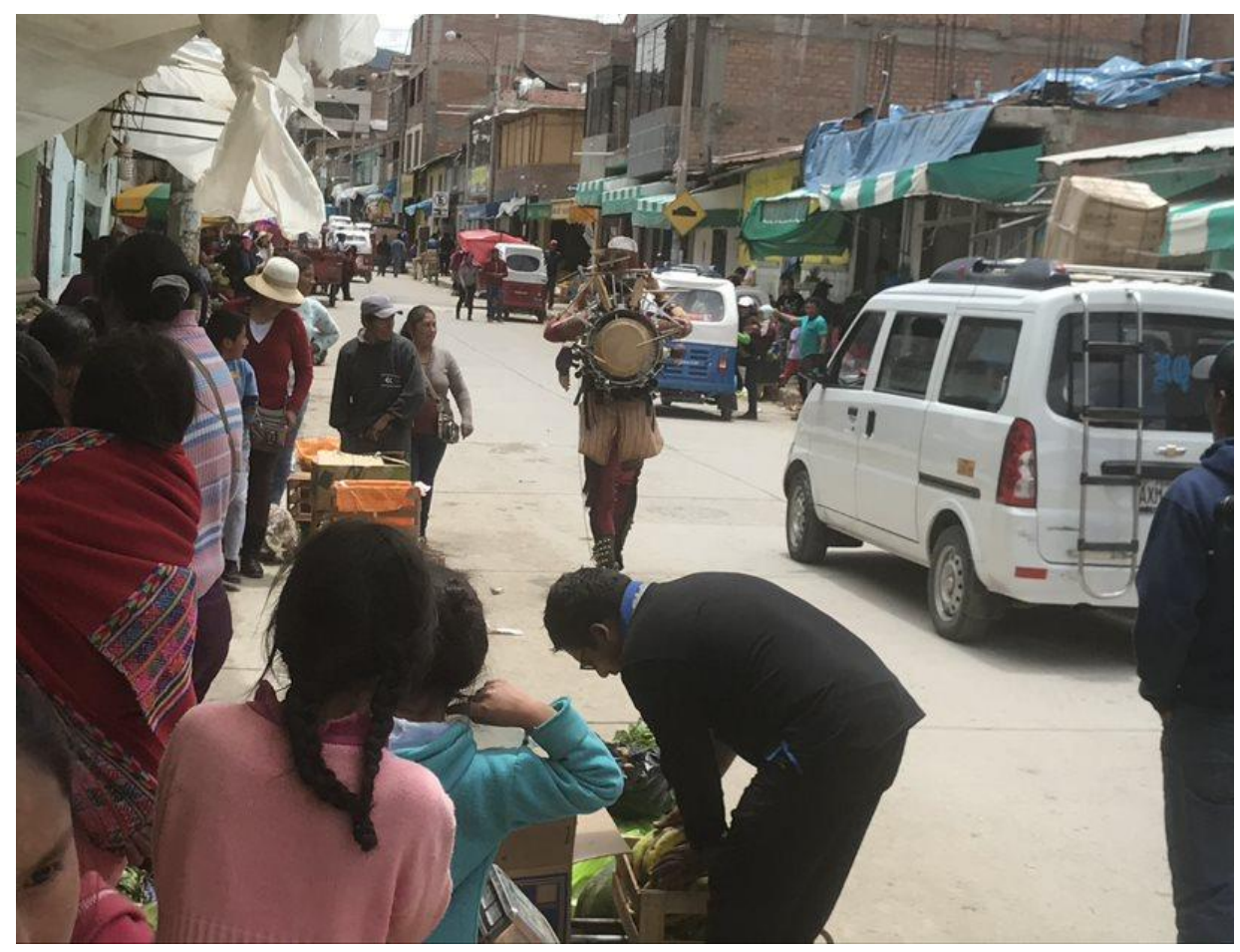

Figura 13. Foto de Ana Lignelli, Feira em Pucchio, Peru, 2018.

Ainda sobre banda temos a possibilidade, na linguagem informal, de outra referência a espaço ou lugar, como volta, passeio, giro, parte lateral e pedaço. Mesmo que este se assemelhe a uma fuga ou um cooper matinal em paisagem cósmica, pueril e pavimentada (ver figura 14).

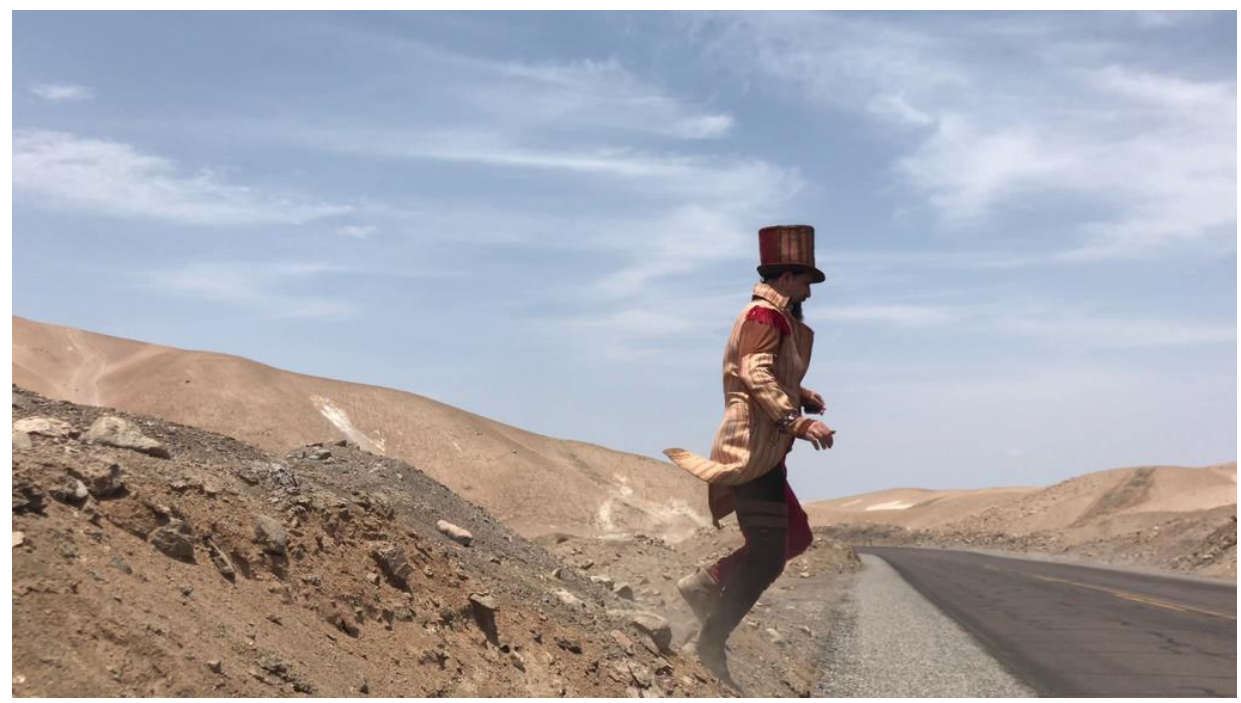

Figura 14. Foto de Sulian Vieira, Ilo, Peru, 2018.

DeBanda, o espetáculo, já inicialmente se diferencia das demais acepções pela visualidade da palavra em que são impressas duas letras maiúsculas, tornando-se assim, automaticamente, um substantivo próprio junto a um coletivo que é evidenciado pela subversão gráfica. Essa subversão da língua vernácula, para os mais tradicionalistas, já poderia ser motivo de um destroçar da mesma no sentido já explicitado (ver figuras 8 e 15). 


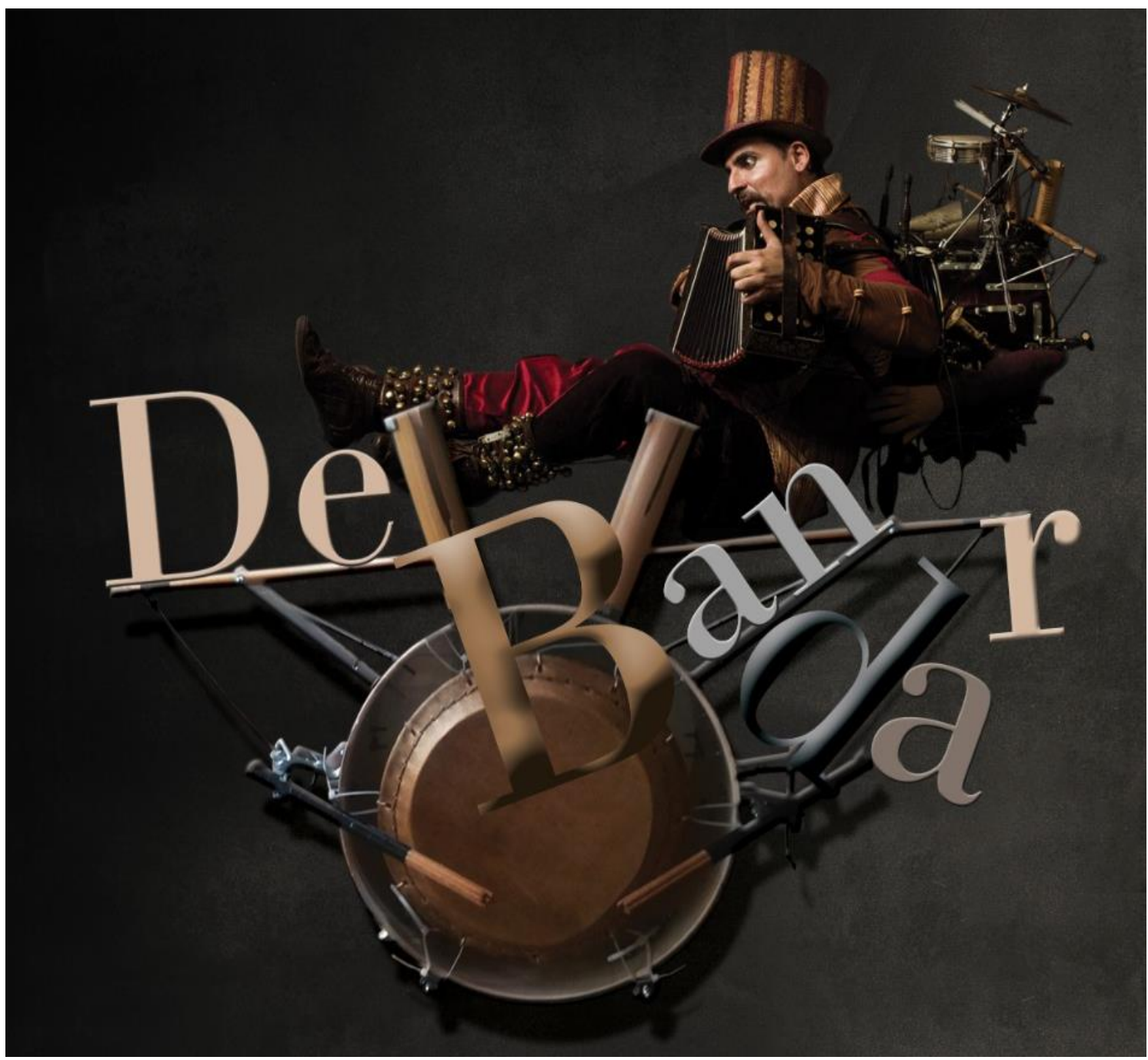

Figura 15. Foto de Diego Bresani e Design de João Lucas².

A máquina e o performer relacionam-se em um estado de destroçamento continuo. Estes se dispersam em pluralidades - tanto peças quanto vertebras se desgastam, se transformam e requerem manutenção. Suor e óleo são derramados durante o espaço e o tempo da cena, confundindo os papeis de marionete e marionetista, de conduzido e condutor. Na violência dessa relação orgânicomaquinal, tudo se quebra e tudo se transforma, mas o que resta? (ver figura 16).

2 Fragmento da capa do catálogo DeBanda em português. Disponível em: https://issuu.com/espetaculodebanda/docs/catalogodebandaportugues?fbclid=IwAR1IFvjlLTnLJxCSf9bx Tu7P7S4ujYZ_QLmI5_JgSNawQbxWuwGrBcUV7M. (LIGNELLI; LUCAS; CHAVES, 2019). 


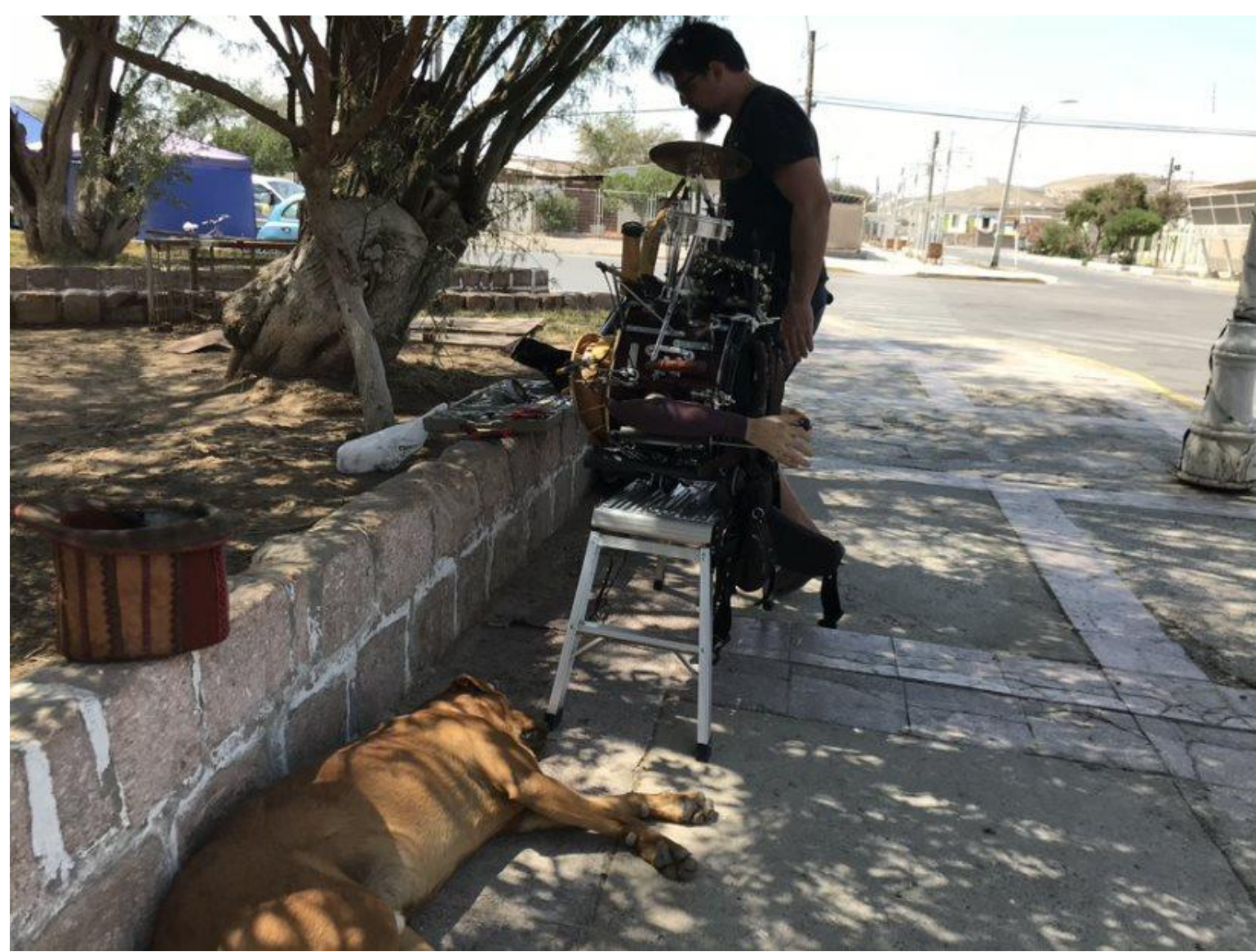

Figura 16. Foto de Sulian Vieira, Pozo Almonte, Chile, 2018.

O que resta é procurar caminhos e por vezes inventá-los. DeBanda espalhase, foge, fracassa, rodeia, subverte o vernáculo, desgasta o corpo, complementa as bandas, entra em exílio e proclama suas aventuras em uma diversidade de lugares:

Entre 2017 e 2018 debandamos por Singapura e circulamos pelo Brasil (estados de GO e MS), Paraguai, Argentina, Uruguai, Chile e Peru. Tal Façanha se deu em um motor home equipado com um sistema de som e de iluminação em que foram realizadas 33 performances, em praças, parques, escolas e ruas públicas, oficinas e igrejas. Estas ocorreram em cidades de pequeno porte (até 100 mil habitantes segundo IBGE) e visavam uma celebração da diversidade tendo como ponto de partida diálogos com as tradições locais (LIGNELLI, SILVEIRA, 2020, p. 288) 


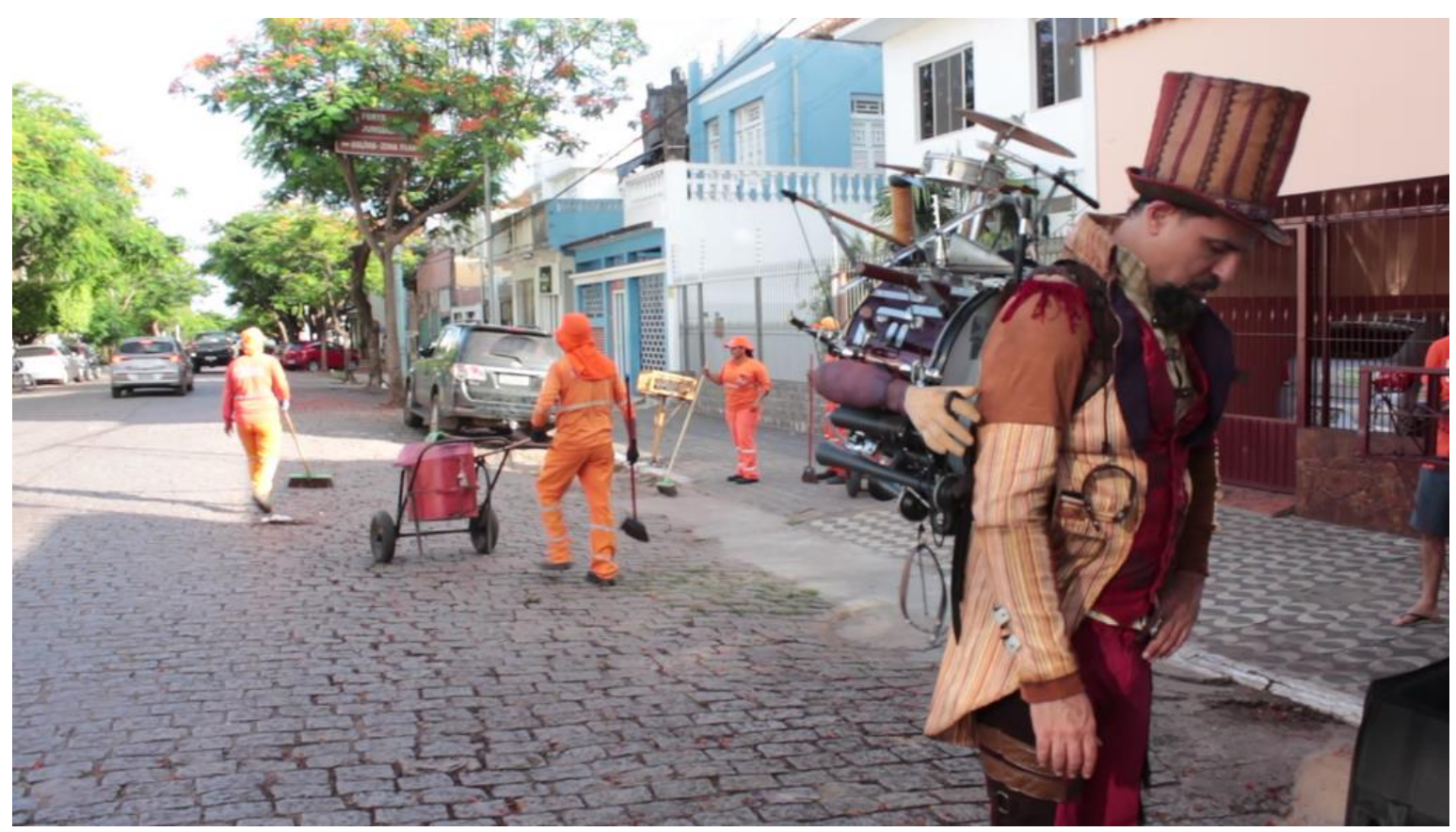

Figura 17. Foto de Sulian Vieira, Corumbá, Mato Grosso do Sul, 2017.

A máquina em si já o torna legião. Quando a máquina quebra, racha seu mundo, escapa a relação padrão com a marionete, multiplica seu fracasso e instaurase o abismo, mas o que resta? (ver figura 18).

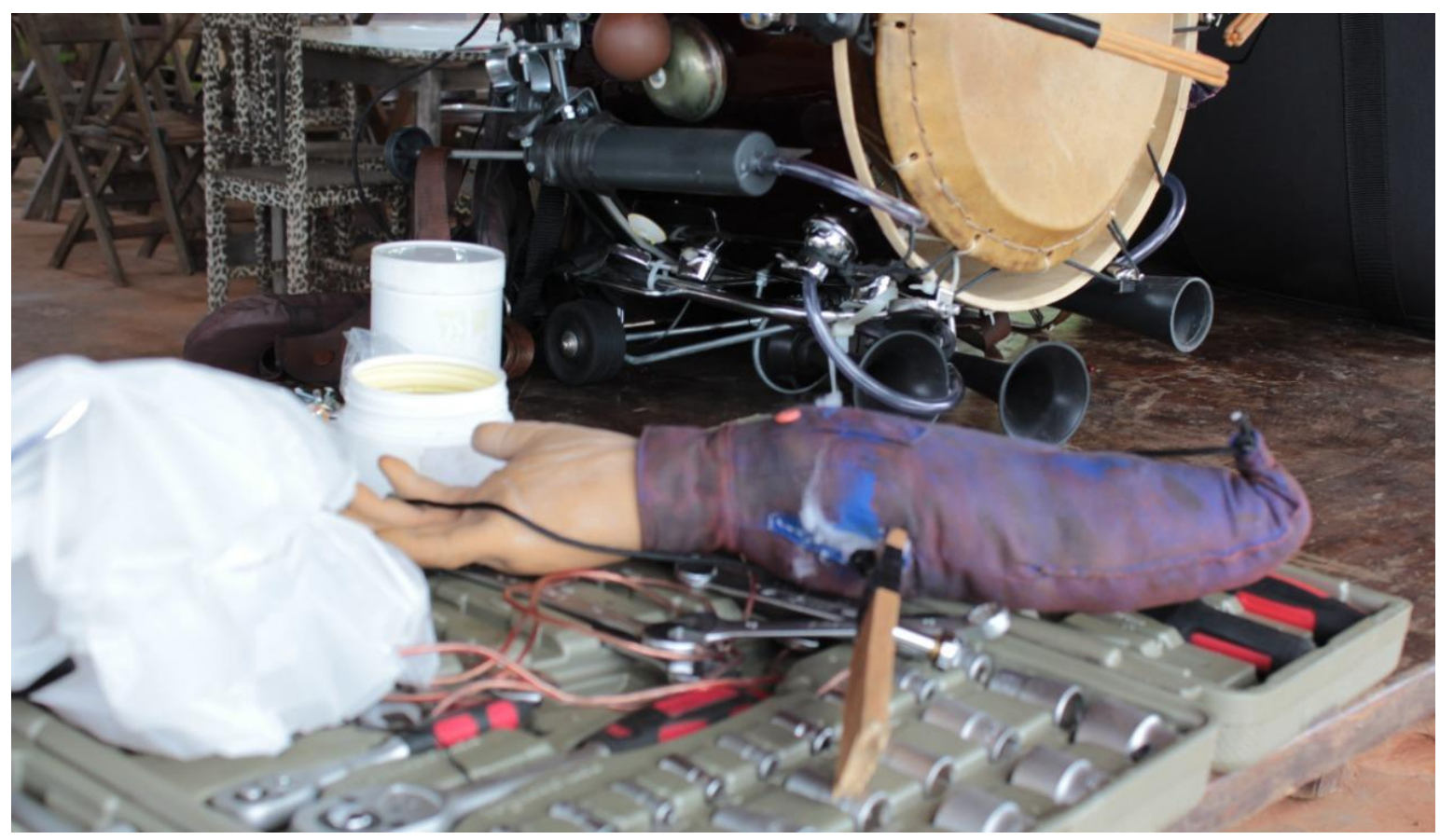

Figura 18. Foto do autor, Miranda, Mato Grosso do Sul, 2017.

Resta evidenciar não-humanos enquanto actantes protagonistas, por mais que isso possa soar utópico, uma vez que:

[...] o mosquito é tão real quanto Napoleão, e o plástico no saco de lixo não é menos actante que a ogiva nuclear. Nós não conseguimos reduzir esses objetos a sua aparência na consciência ou seus atributos definidos pela linguagem (HARMAN, 2009, p.34, tradução nossa) 
Resta reconhecer o esfacelamento de cada actante sonoro quando apartado do SerBanda e consequentemente da redeDeBanda. Latour destaca que:

Em contrapartida, se insistirmos na decisão de partir das controvérsias sobre atores e atos, qualquer coisa que modifique uma situação fazendo diferença é um ator - ou, caso ainda não tenha figuração, um actante. Portanto, nossas perguntas em relação a um agente são simplesmente estas: ele faz diferença no curso da ação de outro agente ou não? Haverá alguma prova mediante a qual possamos detectar essa diferença? A resposta de senso comum seria um "sim" sonoro. Se você puder, com a maior tranquilidade, sustentar que pregar um prego com ou sem um martelo, ferver água com ou sem uma panela, transportar comida com ou sem um cesto, andar na rua com ou sem roupas, zapear a televisão com ou sem o controle remoto, parar um carro com ou sem o freio, fazer um inventário com ou sem uma lista administrar uma empresa com ou sem a contabilidade são exatamente as mesmas atividades, que a introdução desses implementos comuns não muda nada 'de importante' na realização de tarefas, então [...] (LATOUR, 2012, p.108)

Não restariam destes atos, rastros advindos de palavras, calor, sons, contatos, peso, hálitos, imagens e outras reminiscências do momento (ver figura 19).

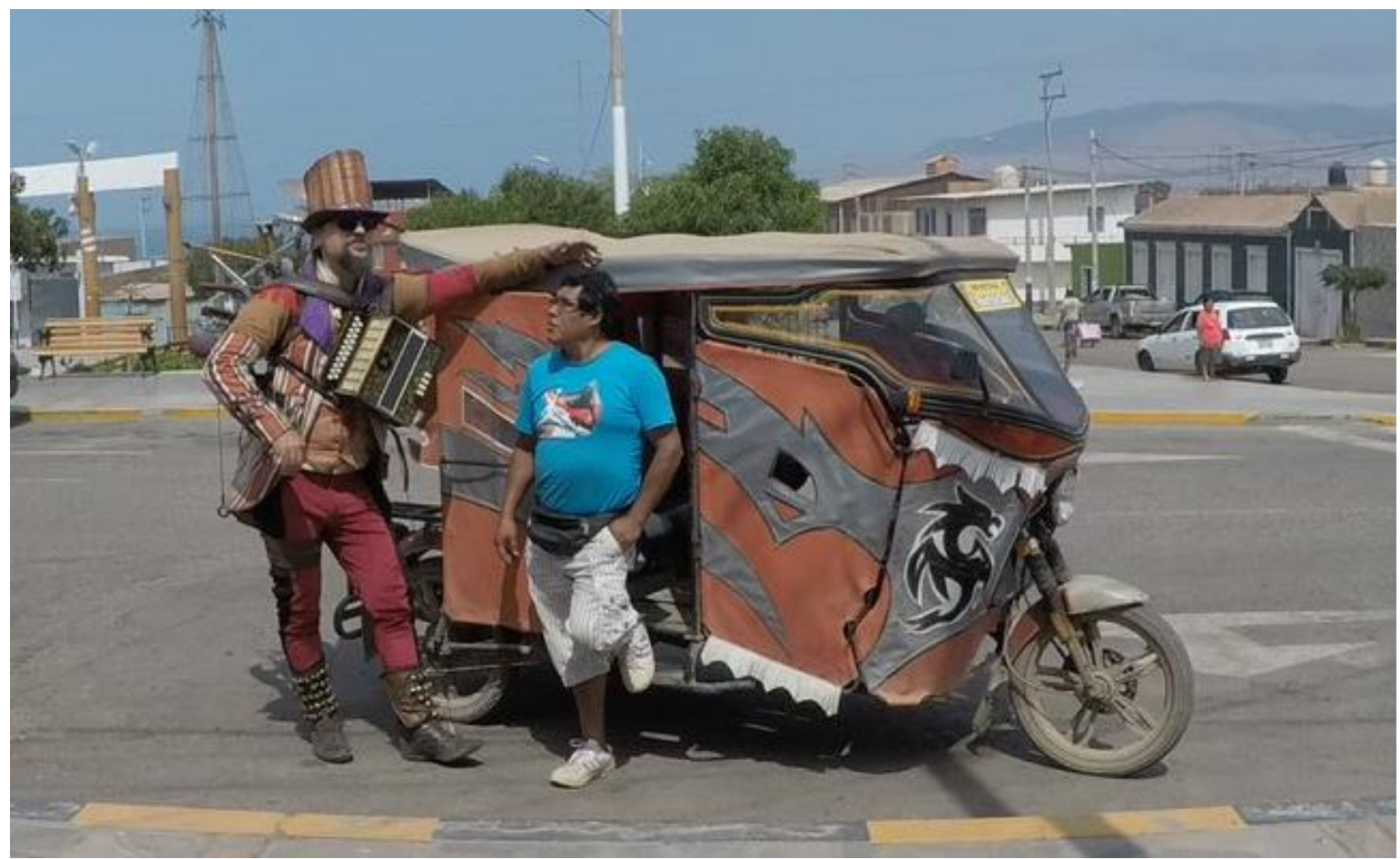

Figura 19. Foto de Sulian Vieira, Praça em Chala, Peru, 2018.

Resta reconhecer as ontologias de cada partícula conectada à traquitana por meio de moléculas aparentemente infinitas (ver figura 20). 
[...] labirinto de dezenas de metros de cordões e cabos de aço de diferentes espessuras, centenas de parafusos, ruelas e porcas, mãos francesas de tamanhos variados, passadores de corda, abraçadeiras de plástico e de metal, ganchos, fivelas, fechos e prolongadores diversos, pedaços de madeira, ferragens de bateria, espuma, rolos de fita de alta fusão, colas adesivas, fitas adesivas, fita de lona de caminhão, fibra acrílica de enchimento, tinta de tecido, carrinho de compras e mochila dão liga a um tambor de cabaça, um tamborim, dois reco-recos, um pedal duplo de bateria, um prato, um bumbo, duas claves cubanas, uma campainha de hotel antigo, três buzinas a ar, dois agogôs, um kazoo, uma surdina de trompete, nove apitos, seis baquetas sendo duas luminosas e uma com sete hastes de nylon enfeixadas, mais duas próteses de braços humanos ergue uma máquina tocável de aproximadamente $30 \mathrm{~kg}$ cujo desígnio principal é o prolongamento do tocador e a multiplicação das suas virtualidades sônicas [...] (LIGNELLI, LUCAS, 2018, p. 154).

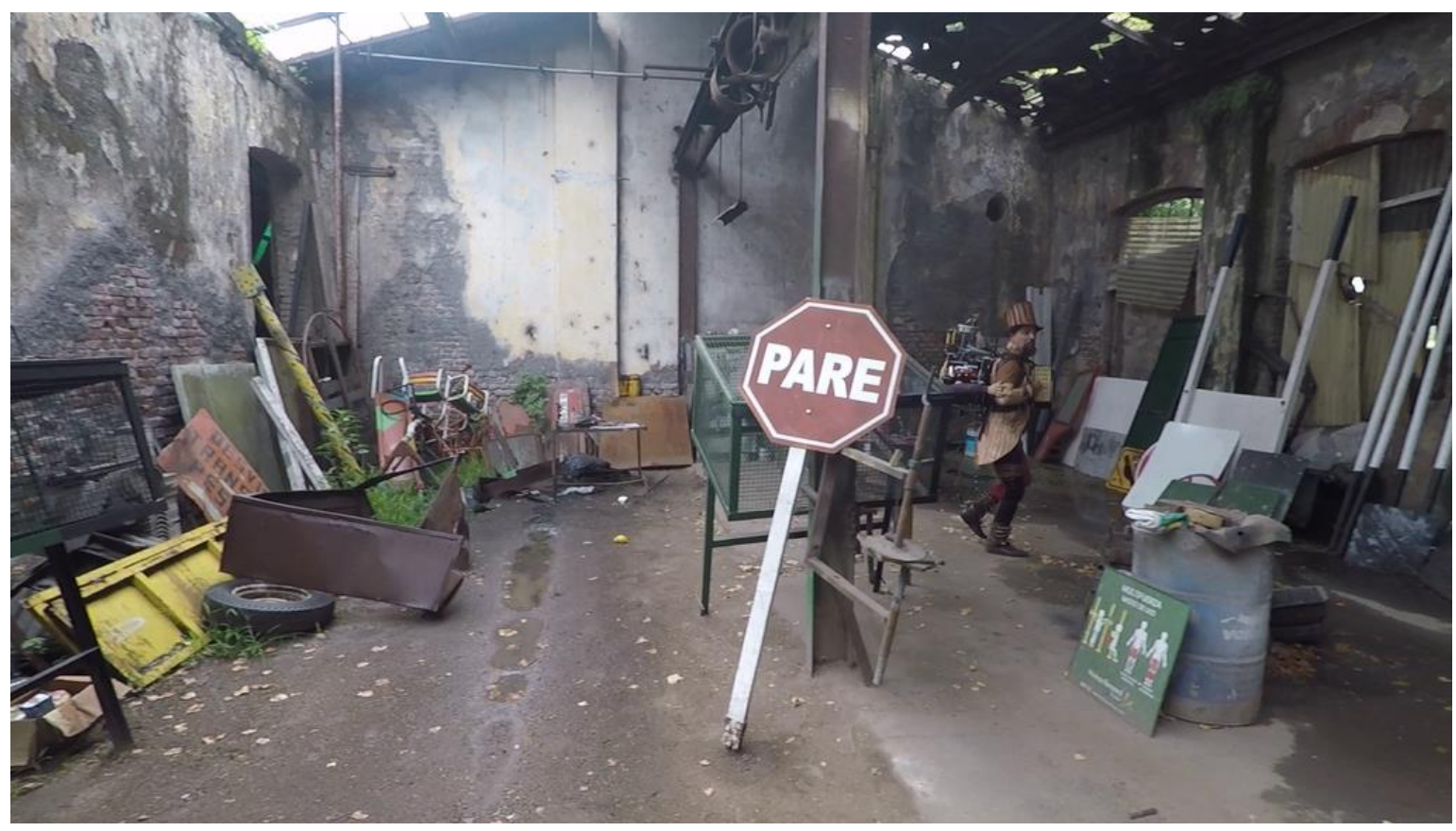

Figura 20. Foto de Sulian Vieira, Huinca Renancó, Argentina, 2018.

Resta viver o fracasso sem que isso estagne o desejo. Resta arriscar mesmo que lhe custe a expulsão do meio. Resta permitir que outrem invada o que era. Resta a violência de um amor nada humano, nada romântico, quiçá objetal (ver figura 21).

Qualquer que seja a etiqueta, a questão é sempre a de reatar o nó górdio atravessando, tantas vezes quantas forem necessárias, o corte que separa os conhecimentos exatos e o exercício do poder, digamos a natureza e a cultura. Nós mesmos somos híbridos, instalados precariamente no interior das instituições científicas, meio engenheiros, meio filósofos, um terço instruídos sem que o desejássemos; optamos por descrever as tramas onde quer que estas nos levem (LATOUR, 1998, p.9) 


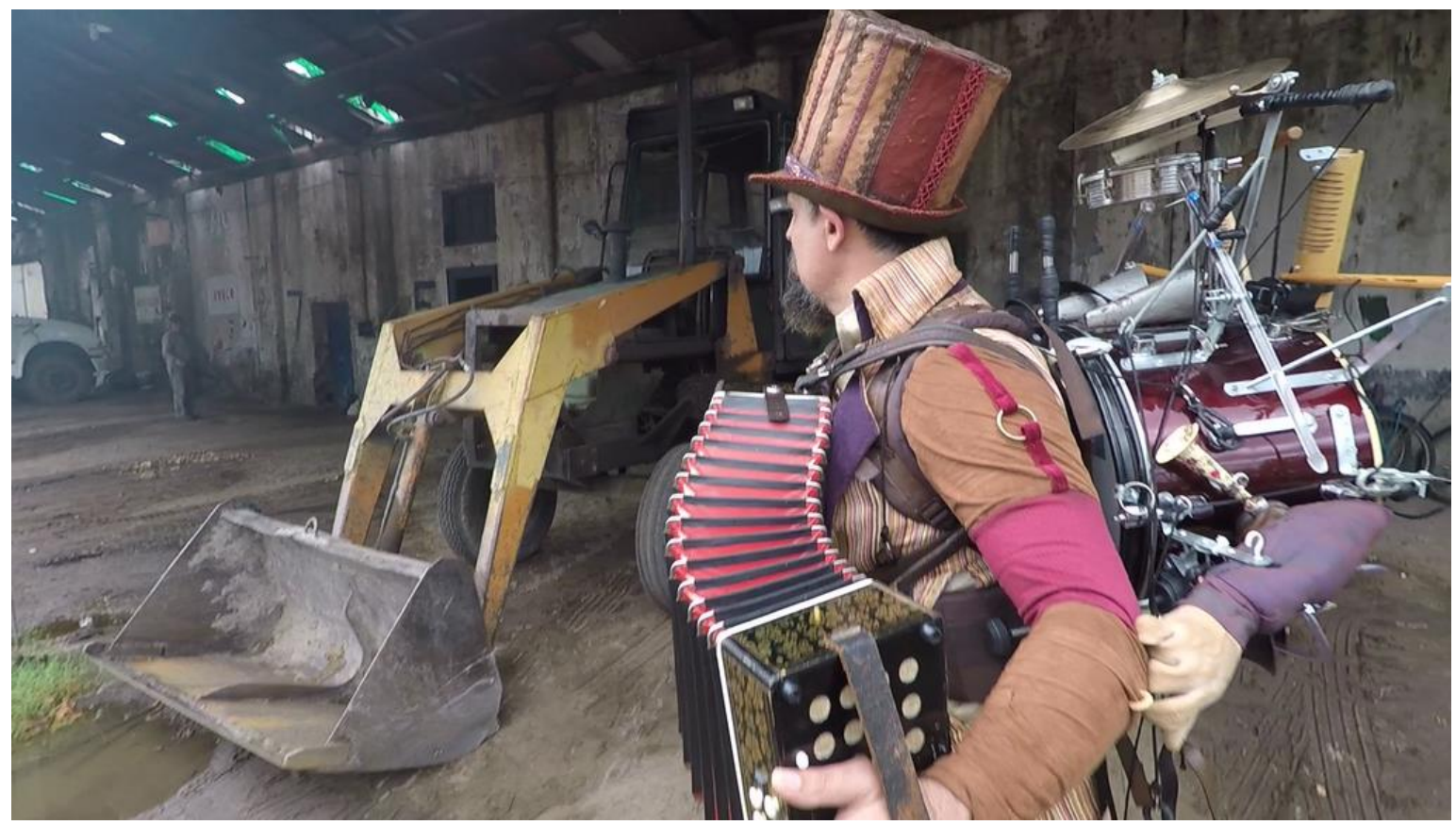

Figura 21. Foto de Sulian Vieira, Huinca Renancó, Argentina, 2018.

Resta a borda como morte e rede (ver figura 22). Borda como palco e rede. Como pulso em seu último movimento em rede. Rede que desata em trama. Trama que se definha em linha. Linha que nos permite ser e conectar. Conexão "mais flexível que a de sistema, mais histórica que a de estrutura, mais empírica que a de complexidade, a rede é o fio de Ariadne destas histórias confusas" (LATOUR, 1998, p.9).

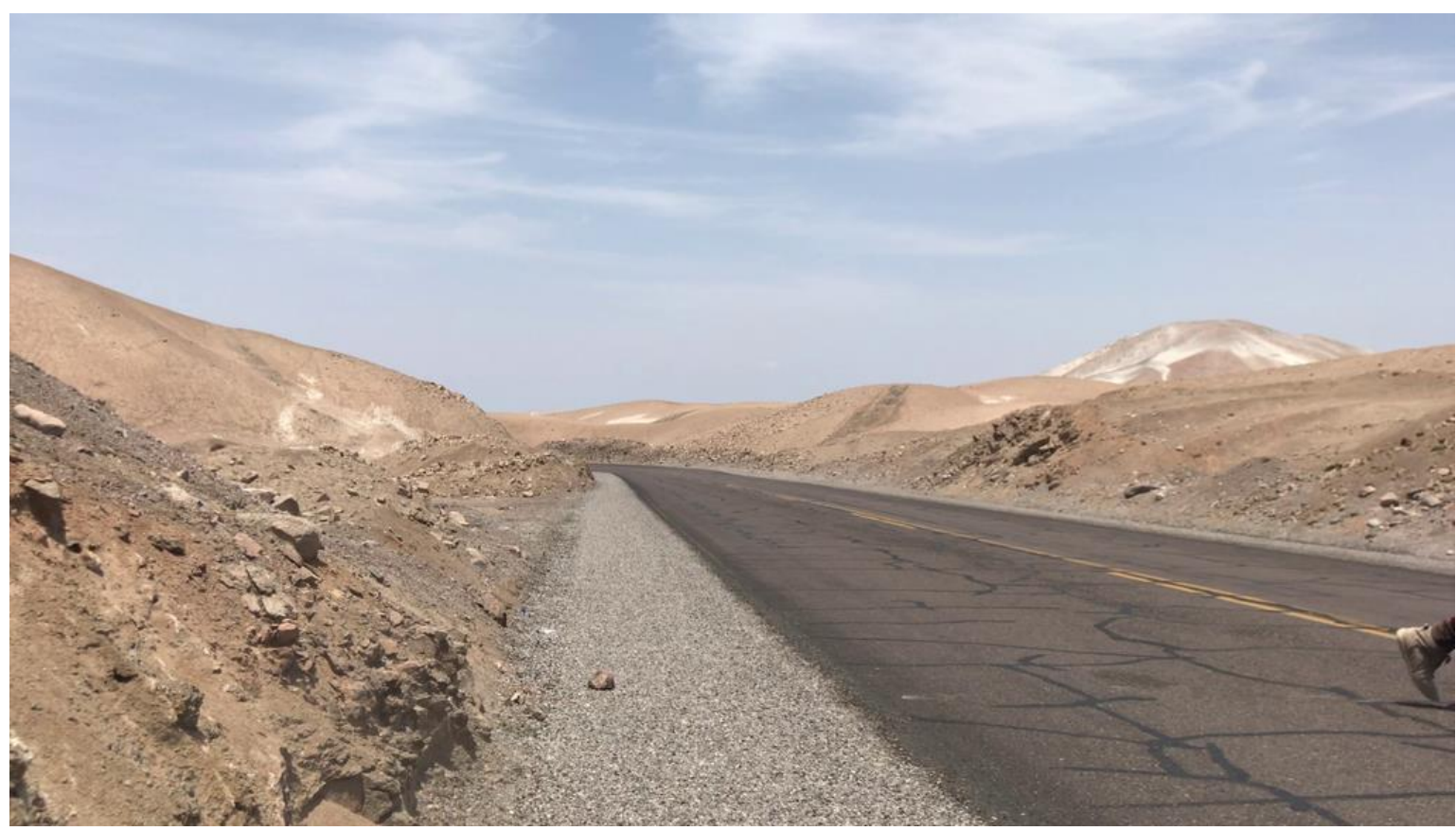

Figura 22. Foto de Sulian Vieira, Ilo, Chile, 2018.

Resta o comprometimento do coletivo perante ao fracasso de alguma coisa em cena, um encontro bem sucedido que supera o malogro na medida que Ihe é 
possível. Como sabido, não estamos falando exclusivamente de uma coletividade de humanos presentes durante a performance, mas, sobretudo, de actantes que perenemente agem em torno do dionisíaco acordo da performance teatral na mira da catarse coletiva (ver figura 23).

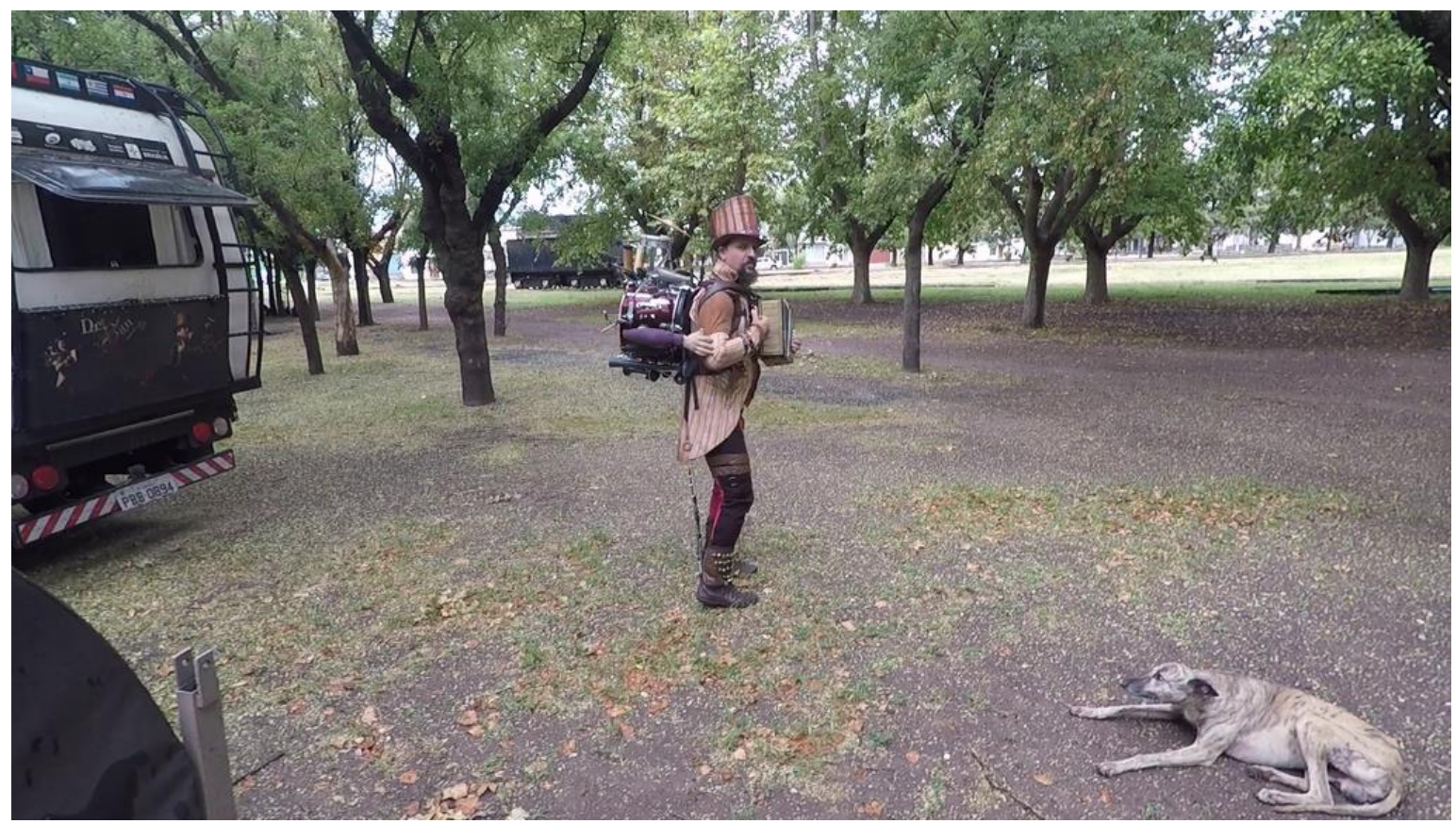

Figura 23. Foto de Sulian Vieira, Taltal, Peru, 2018.

Resta a relação. Relação que, em meio ao encontro, não se sabe quem é a marionete e quem é a marionetista; quem é o aniversariante e quem é o penetra; quem celebra e quem inveja; quem se importa e quem só quer comer o bolo... Que rede é essa? (ver figura 24).

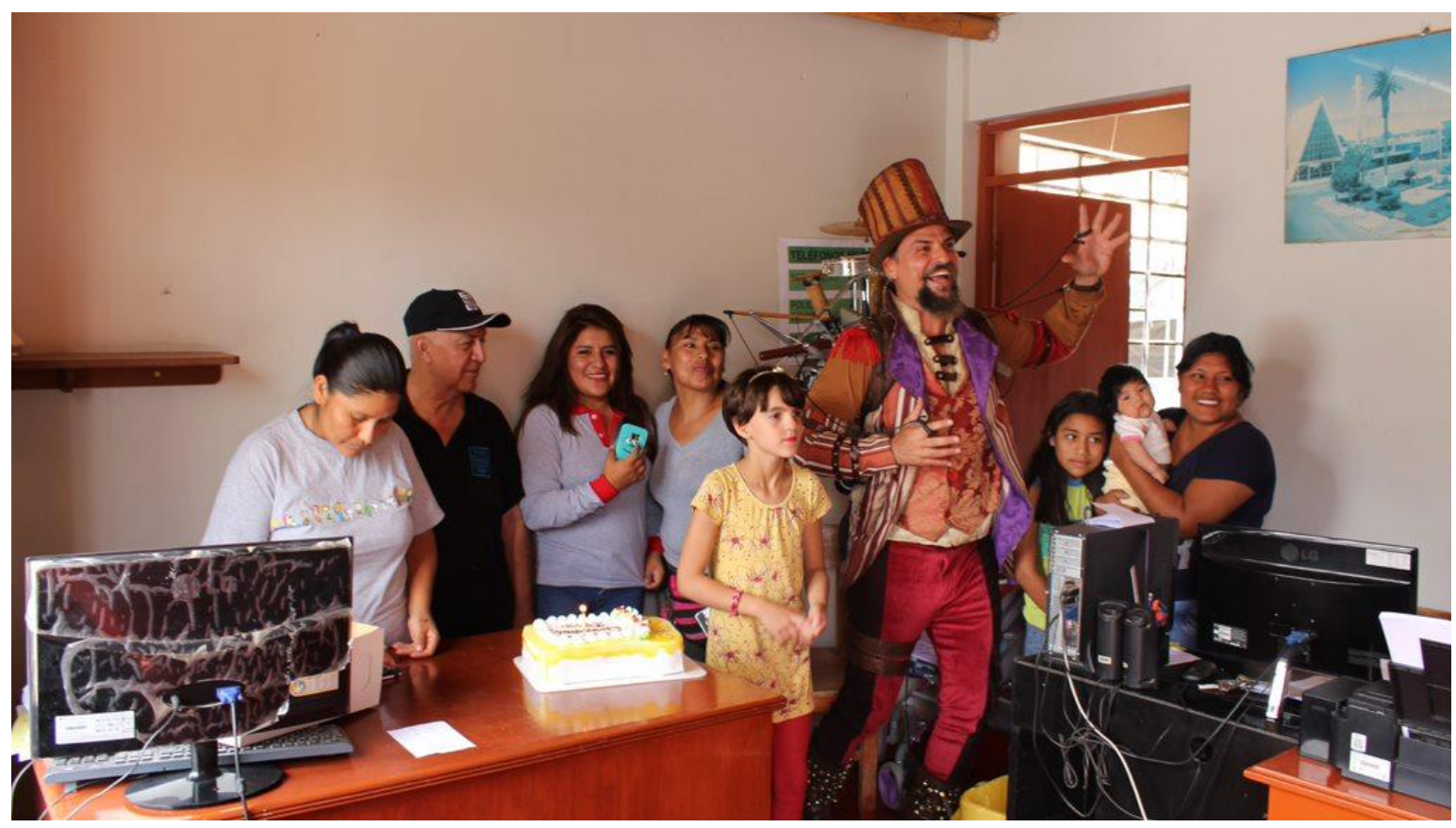

Figura 24. Foto de Sulian Vieira, Camaná, Peru, 2018. 
Sendo ainda mais incisivo, será relevante perguntar quem, o quê, como e/ou quanto? Quanto há de DeBanda em SerBanda? Como SerBanda é DeBanda? O que é debandar? Será que isso é passível de discussão? Essa alternância de poder deixa feliz qualquer comentarista político e permite que o acontecimento flua com sua capenga plenitude. A convivência de DeBanda faz com que não tenhamos grandes lapsos temporais que abram brechas a insurgências tirânicas entre orgânicos, outros orgânicos e qualquer inorgânico em função da premência dos atos concatenados entre as coisas (ver figura 25).

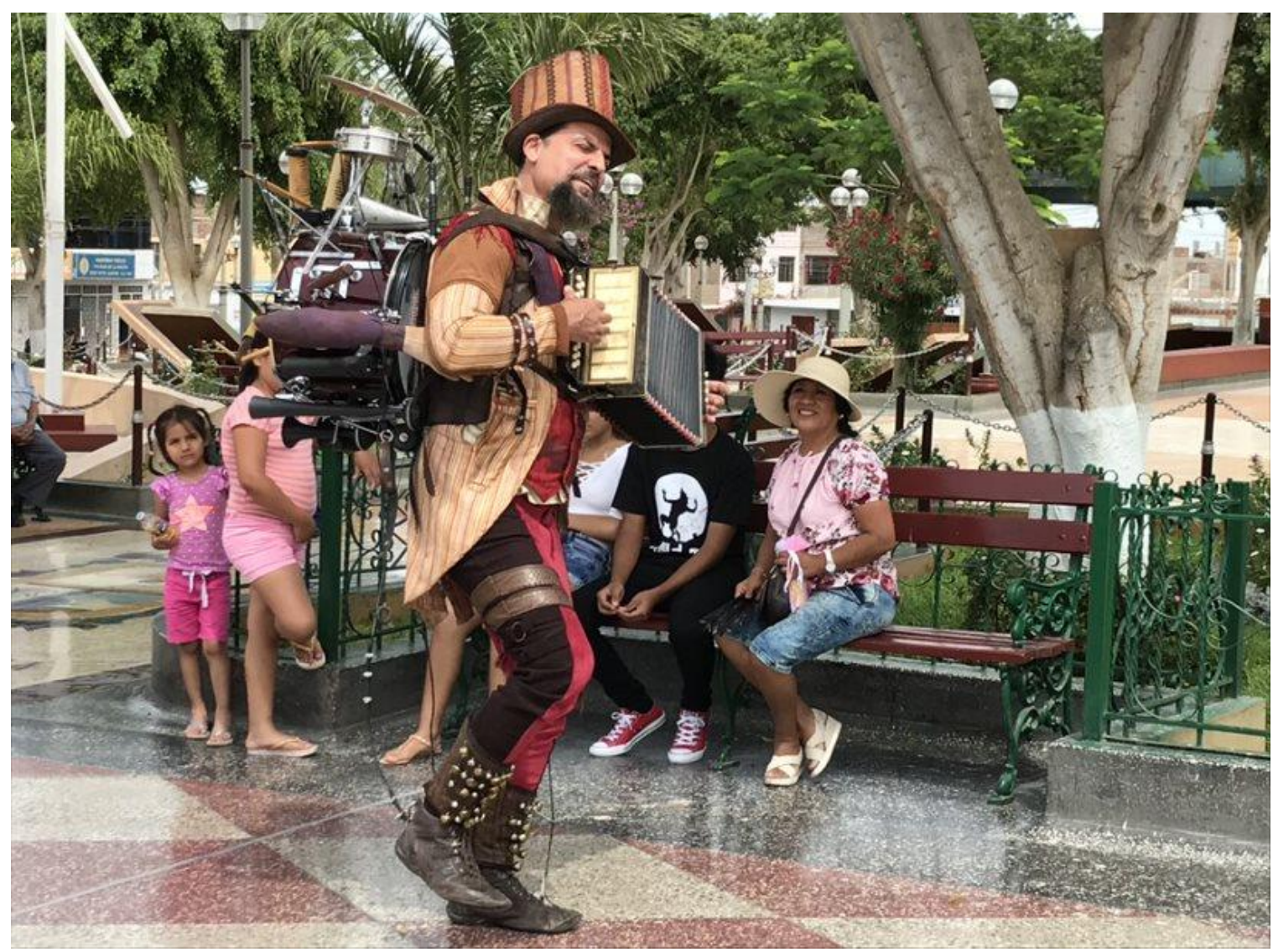

Figura 25. Foto de Ana Lignelli, Nazca, Peru, 2018.

Resta dar tempo, resta perder tempo, assim como não perder tempo, para não deixar tempo à tirania. O tempo do teatro é efêmero e tende a uma finitude prematura, que normalmente se contrapõe ao desejo da/o artista. Em Debanda esses conflitos são potencializados. Resta a centelha que queima o invisível (ver figura 26). 


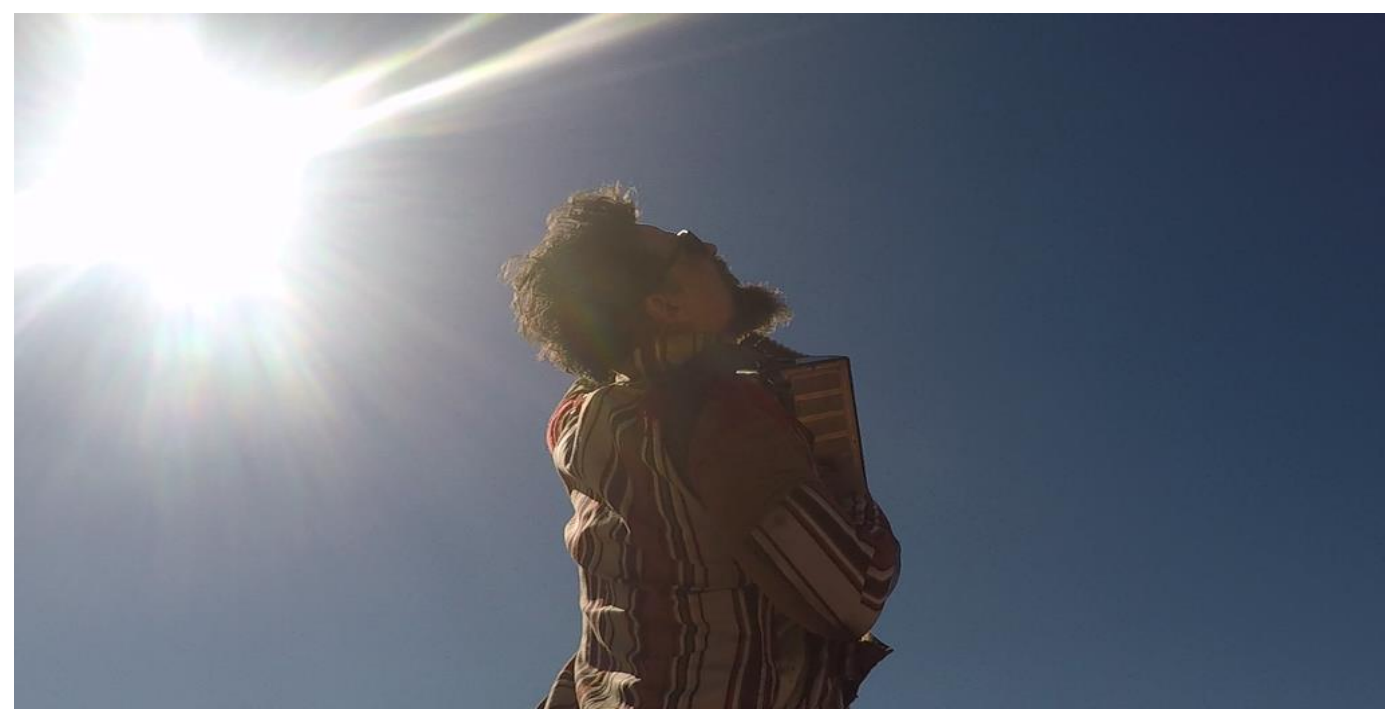

Figura 26. Foto de Sulian Vieira, Copiapó, Chile, 2018.

Ao mesmo tempo, um desejo do intérprete ao finalizar cada sessão é de que esta nunca sequer tivesse ocorrido. Afinal, se desvencilhar do SerBanda, seus 30 quilos e 23 instrumentos, equivale a um alívio, um prazer, um petit mort, como definido em francês traduzido livremente como gozo, mas que significa, "ao fim" e "a cabo", uma pequena morte, mas nem por isso destituída de grandes dores (ver figura 27).

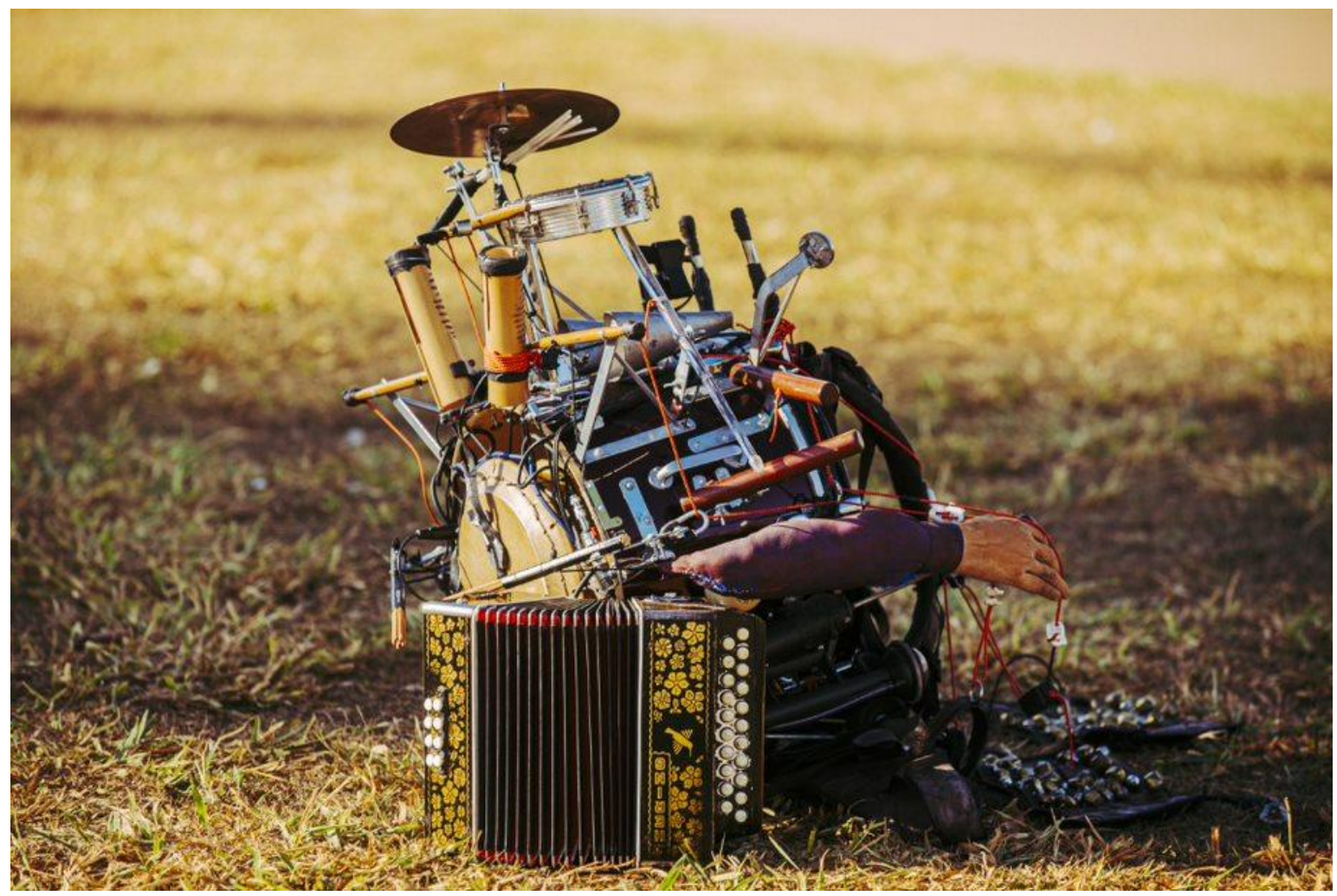

Figura 27. Foto de Jacqueline Lisboa, nas proximidades da Torre de TV, Brasília, 2019.

Resta o excesso. A diferença que sobra. A quantidade que vaza. Que passa da medida. Aritmética que se funde em coisa. Normalidade inadmissível. Ensaios que redundam. Onde o necessário sobeja. Onde o controle fracassa. Onde impera a 
desmesura. Onde humano e não-humano se refletem. Se abundam. DeBanda foi banido. Não se sabe de onde. Não se sabe por quem. Não se sabe se por amor, displicência ou crime. Com qualquer público excede, proclama, proíbe, ordena, declara, decreta e desanda (ver figura 28).

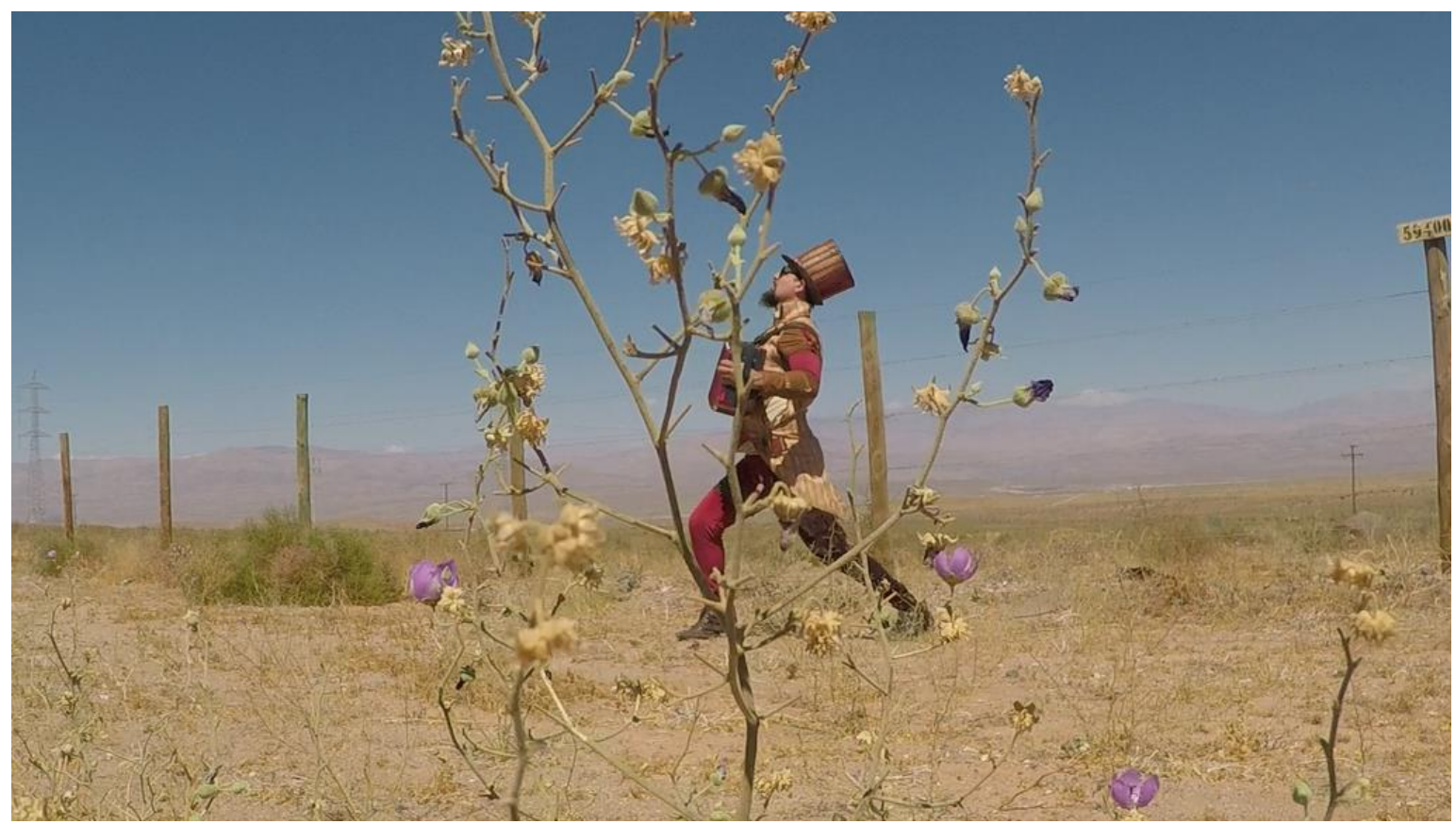

Figura 28. Foto de Sulian Vieira, nas proximidades de Mendoza, Argentina, 2018.

Nessas andanças, ao se afastar de si também se aproxima. Ao se espalhar junta toda uma criação de visualidades e sonoridades que se indeterminam temporal e espacialmente (ver figura 29 ).

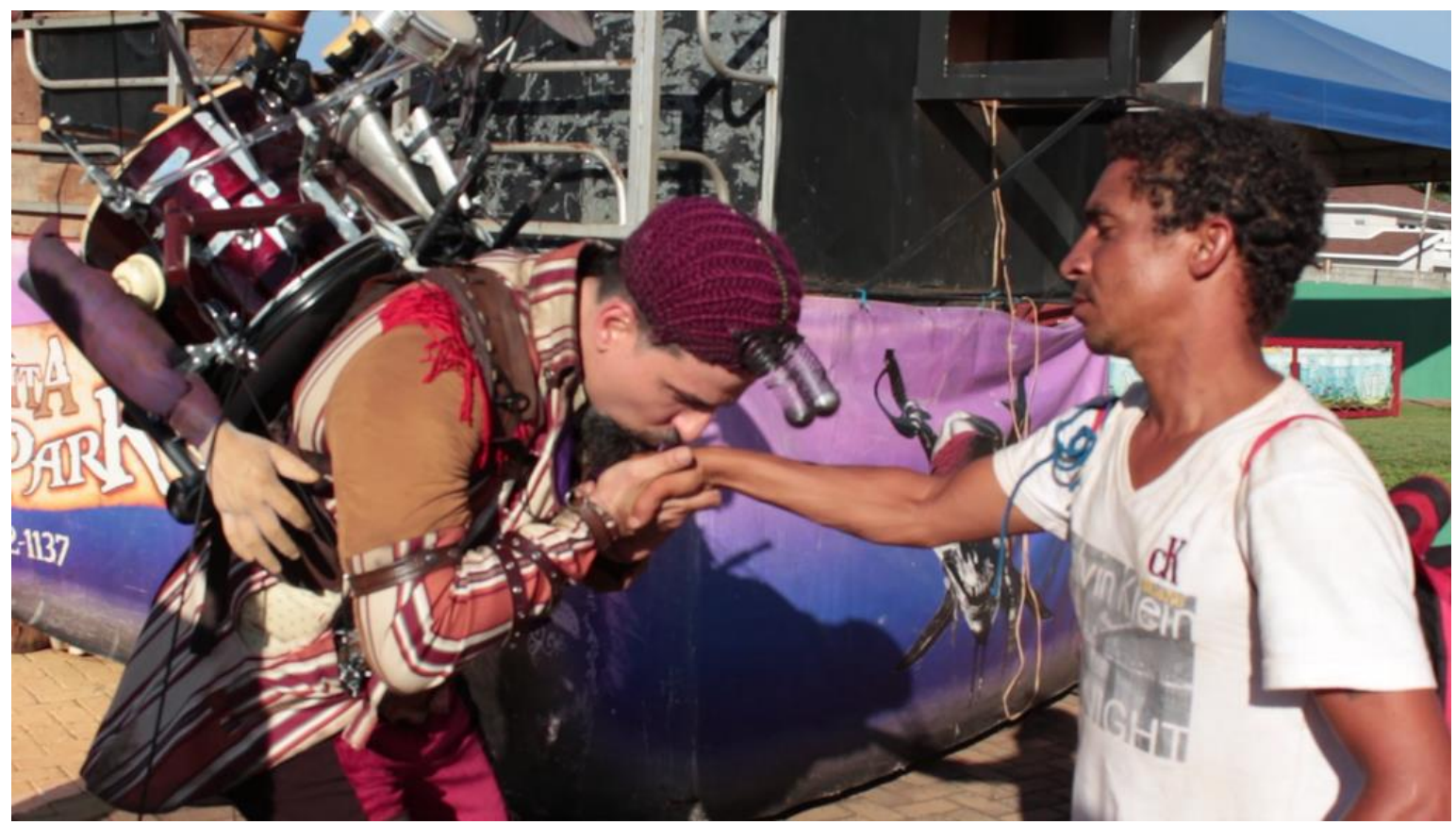

Figura 29. Foto de Sulian Vieira, Chapadão do Sul, Mato Grosso do Sul, 2017.

Entre cantos, vergonhas, desfeitas, descasos, gracejos, cegueira, vazio, contágios, luz, aridez e um ciborgue vintage com uma orquestra capenga. Jorram 
celebrações, brasas, línguas, quedas, matizes, cenários, sudorese, gelo, palavrório e transeuntes passíveis de qualquer reação. Por vezes, sobram olhares caninos, reparo de membros, piscadelas maquinais, bandas instantâneas, vínculos de sangue e resíduos cósmicos desvelados camufladamente. Convivências acidentais, rupturas enlutadas, leveza intransportável, caminhos inadmissíveis, vislumbres idílicos, brindes infindos, reflexos infantes e sons que se excedem em justa suficiência.

Resta uma cena DeBandada.

\section{Referências}

BARÃO VERMELHO. Maior Abandonado, Rio de Janeiro: Opus Columbia. 1 disco sonoro (35 $\mathrm{min}$ ), estéreo.

BRYANT, Levy. Democracy of Objects. Michigan: Open Humanities Press, 2011.

HARMAN, Graham. Prince of Network: Bruno Latour metaphysics. Melbourn: Re.Press, 2009.

LATOUR, Bruno. Jamais fomos modernos: ensaio de antropologia simétrica. Rio de Janeiro: Editora 34, 1994. Tradução de Carlos Irineu da Costa.

LATOUR, Bruno. Reagregando o social: uma introdução à teoria do ator-rede. Tradução de Gilson Carlos Cardoso de Souza. Salvador: Edufba, 2012.

LIGNELLI, César; LUCAS, João; CHAVES, Fred. DeBanda: catálogo português. PPGCEN 2019. Disponível em:

https://issuu.com/espetaculodebanda/docs/catalogo_debanda_portugues?fbclid=Iw AR1IFv-jILTnLXCSf9bxTu7P7S4ujYZ_QLmI5_JgSNawQbxWuwGrBcUV7M. Acesso em: 13 maio 2020.

LIGNELLI, César; SILVEIRA, Victor Hugo. DeBanda. Voz e Cena, Brasília, p. 271315, 29 jun. 2020. Disponível em:

https://periodicos.unb.br/index.php/vozecena/article/view/31570.

LUCAS, João; LIGNELLI, César. DeBanda e a máquina contemporânea. Revista

VIS: Revista do Programa de Pós-Graduação em Arte, v. 17, n. 2, p. 152-172, 1 out. 2018. 